PUBLISHED BY THE AMERICAN MUSEUM OF NATURAL HISTORY CENTRAL PARK WEST AT 79TH STREET, NEW YORK, NY 10024 Number 3329, 23 pp., 76 figures, 1 map, 1 table

\title{
A New Genus of Pholcid Spiders (Araneae: Pholcidae) Endemic to Western Cuba, with a Case of Female Genitalic Dimorphism
}

\author{
BERNHARD A. HUBER ${ }^{1}$ AND ABEL PÉREZ GONZÁLEZ ${ }^{2}$
}

\begin{abstract}
Four species of Ciboneya Pérez, n. gen. are described from western Cuba: C. nuriae, n. sp. from La Habana and Pinar del Rio Provinces, $C$. odilere, n. sp., $C$. parva, n. sp., and $C$. antraia, n. sp. from Pinar del Rio Province. The species share apophyses on the male cheliceral fangs, corresponding pockets or modified areas on the female epigynum, and several details of the male pedipalps. Vertical hairs on the tibiae and metatarsi of the male legs and a retrolateral coxa apophysis on the male palp place the genus close to other Central and South American genera of the New World clade of pholcids, but the exact sister group is obscure. The spiders live in the leaf litter and under rocks in humid forests, or near the floor in caves. The females of $C$. antraia show a remarkable dimorphism in their genitalia, with rare intermediate forms. The possibly more frequent occurrence of such a dimorphism and the probable bias toward reporting it as two different species are discussed.
\end{abstract}

\section{INTRODUCTION}

The pholcid fauna of Cuba has been treated in some detail by Franganillo (1930, 1931), Bryant (1940), and Gertsch (1982). The basic result from their work is that most
Cuban pholcids are easily assigned to the genera prevalent on other Islands of the Greater Antilles and in Central America (Modisimus Simon, Anopsicus Chamberlin and Ivie, Leptopholcus Simon). This is also

\footnotetext{
' Kalbfleisch Research Fellow, Division of Invertebrate Zoology, American Museum of Natural History. Present address: Evolutionary Biology, Institute of Zoology, University of Vienna, Althanstr. 14, A-1090 Wien, Austria.

${ }^{2}$ Instituto de Ecología y Sistematica, Habana 8, Cuba.
} 
true for the more recently recorded genus Metagonia Simon (Pérez and Huber, 1999). Only Bryantina Mello-Leitão is endemic to Cuba, but this genus is probably a synonym of Modisimus. It was thus surprising when, beginning in 1990, one of us (APG) found pholcids that could not be assigned to any known genus. Within a few years, three species had been collected, all from western Cuba. In a 1999 trip that was specifically designed to collect, among other things, this new genus, we found yet another species, and we more than doubled the number of available specimens. The results of this and previous collections are reported here.

\section{MATERIALS AND METHODS}

Most of the material studied is in the Instituto de Ecología y Sistematica (IES), Habana, Cuba. Some of the newly collected specimens are deposited in the American Museum of Natural History (AMNH), New York, and in the private collection of the first author (collection BAH). We have not made an intensive effort to find further specimens in existing collections, but four major U.S. museums (AMNH; Museum of Comparative Zoology, Cambridge; National Museum of Natural History, Washington; Field Museum of Natural History, Chicago) seemed to possess no more than one vial all together.

The methods used are described in Huber (2001). All SEM photos were done on a Hitachi S-4700 cold-emission scanning electron microscope. For details of keeping and rearing specimens see the Natural History section under the Ciboneya antraia description below.

\section{CIBONEYA PÉREZ, NEW GENUS}

TyPe SPECIES: Ciboneya nuriae, new species.

ETYMology: The generic name remembers the Ciboney (Siboney), Cuba's earliest human inhabitants, hunter-gatherers whose remains date back to about 5000 B.C. They were later dislodged by Taino peoples and pushed toward the west before they disappeared around 1600 A.D.

Diagnosis: Medium-sized pholcids (total length about 2-4 mm), with globular opisthosoma, relatively short legs (except the cave- dwelling $C$. antraia), and long male pedipalps. Distinguished from other genera by the combination of apophyses on the male cheliceral fangs (figs. 1, 2, 22, 40, 52, 61), a corresponding pair of pockets or modified areas on the epigynum (figs. 14-17, 31-33, 44, 46, $55,66,67)$, unmodified basal segments of the male chelicerae, small AME, many vertical hairs on the tibiae and metatarsi of male legs (fig. 7), and several details of the male pedipalps (see figures of bulbs and procursi).

DESCRIPTION: Total length in males usually about 2-3 $\mathrm{mm}$; only $C$. antraia up to $4 \mathrm{~mm}$. Carapace oval in dorsal view, wider than long; with distinct thoracic groove that does not reach posterior border of carapace. Eight eyes on moderately elevated ocular area; AME very small, others about equal (e.g., figs. 19, 20). Distance PME-ALE large (about $50-70 \%$ of PME diameter). Clypeus unmodified. Male chelicerae with distinctive pair of apophyses on fangs, basal segment not modified; without stridulatory ridges. Male palps long; coxa with retrolateral apophysis (figs. 24, 26, 39, 51, 63); femur long and cylindrical, without ventrodistal apophysis; bulb consisting of ovoid proximal part and mostly membranous embolar division; location of sperm duct opening not established; procursus long, relatively simple, with distinctive ventrodistal sclerotized bulge, dark distally pointed apophysis, and further elements of variable shape. Tarsal organ exposed (figs. 3, 4). Legs relatively short (leg 1 usually $3.5-5 \times$ body length; $9 \times$ in $C$. antraia) and robust (tibia 1 1/d: 15-23; 57 in C. antraia); leg 4 usually longest (leg formula: 4123), only in C. antraia 1423; legs without dark rings; with many vertical hairs on tibiae and metatarsi (decreasing in density from legs 1 to 4 ), usually without curved hairs (present only in $C$. antraia), without spines; retrolateral trichobothrium of tibia 1 at about $25-30 \%$; tarsus 1 with about 20-30 distinct pseudosegments (fig. 8). Opisthosoma about globular, either dark bluish or greenish gray with dark spots, or monochromous ochre gray ( $C$. antraia); large light brown genital plate, and indistinct plate in front of spinnerets; without epiandrous spigots (figs. 10, 11); ALS with only two piriform gland spigots (one pointed, one widened; figs. 12,13), other spinnerets typical for family. 

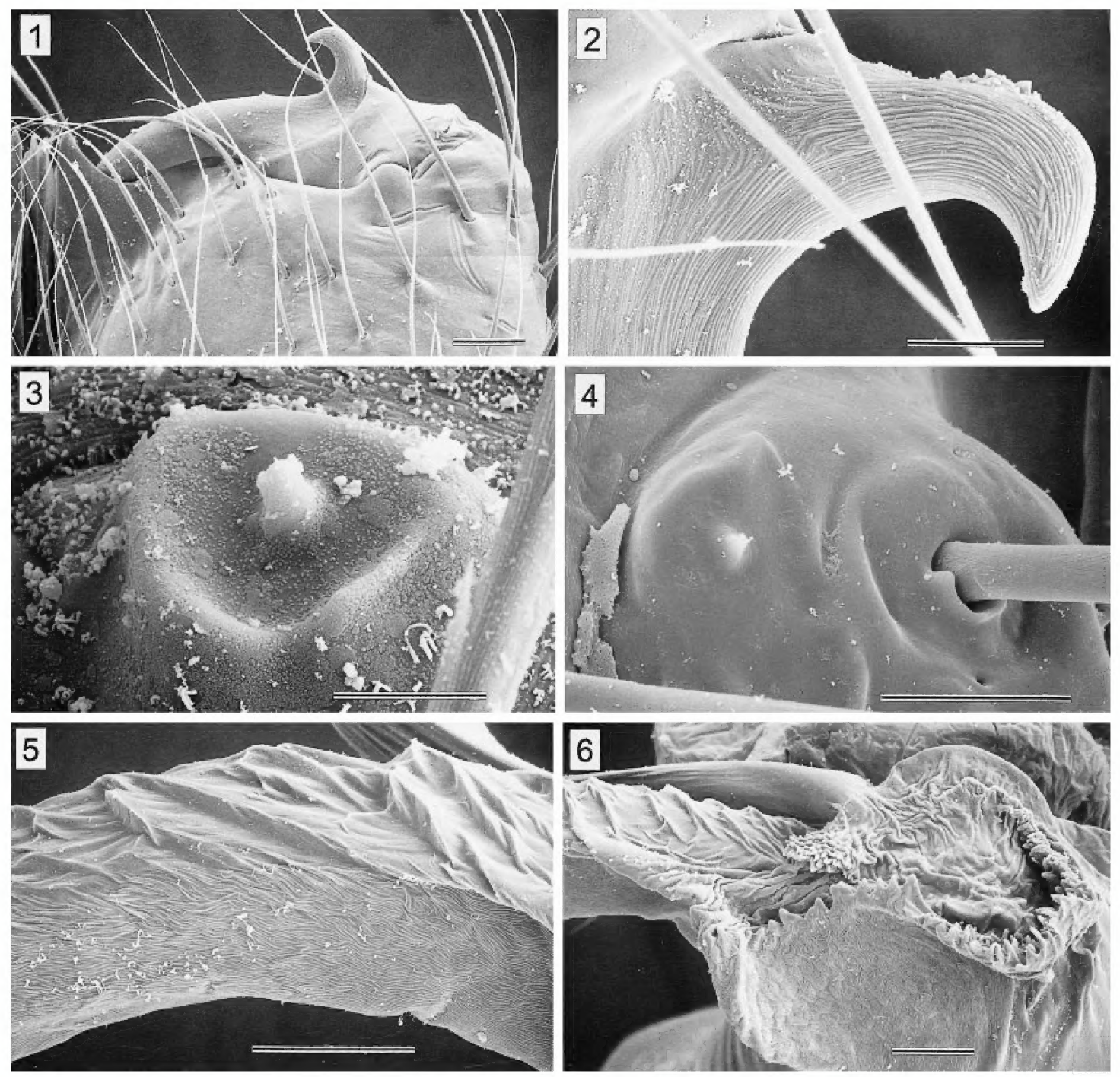

Figs. 1-6. SEM photographs of $C$. antraia $(1,2,4-6)$ and $C$. nuriae (3). 1. Right male chelicera, distal part in frontal view. 2. Apophysis on male cheliceral fang. 3. Female palpal tarsal organ. 4. Male palpal tarsal organ (on left side; hair base on right side). 5. Detail of the long distal projection of the procursus. 6. Distal part of procursus at origin of long apophysis. Scale lines: $40 \mu \mathrm{m}(1,5,6), 15 \mu \mathrm{m}(2,4), 5 \mu \mathrm{m}(3)$.

Sexual dimorphism slight. Female opisthosoma often larger and higher; legs shorter; chelicerae unmodified; tibiae and metatarsi with usual low density of vertical hairs. Epigynum large, with pair of pockets or modified areas in highly variable position. Epigynum shape highly variable even within species (it is therefore not used in the diagnoses below).

Monophyly: All species share the unique procursus (ventrodistal sclerotized bulge, dark distal pointed apophysis). The apophyses on the male cheliceral fangs are shared by other genera (see below) but have possibly independently evolved in Ciboneya.

GENERIC RELATIONSHIPS: The presence of a retrolateral apophysis on the male palpal coxa places Ciboneya in the New World clade sensu Huber, 2000. Three South American genera (Chibchea Huber, Galapa Huber, Blancoa Huber) share the apophyses on the male cheliceral fangs, but otherwise these 

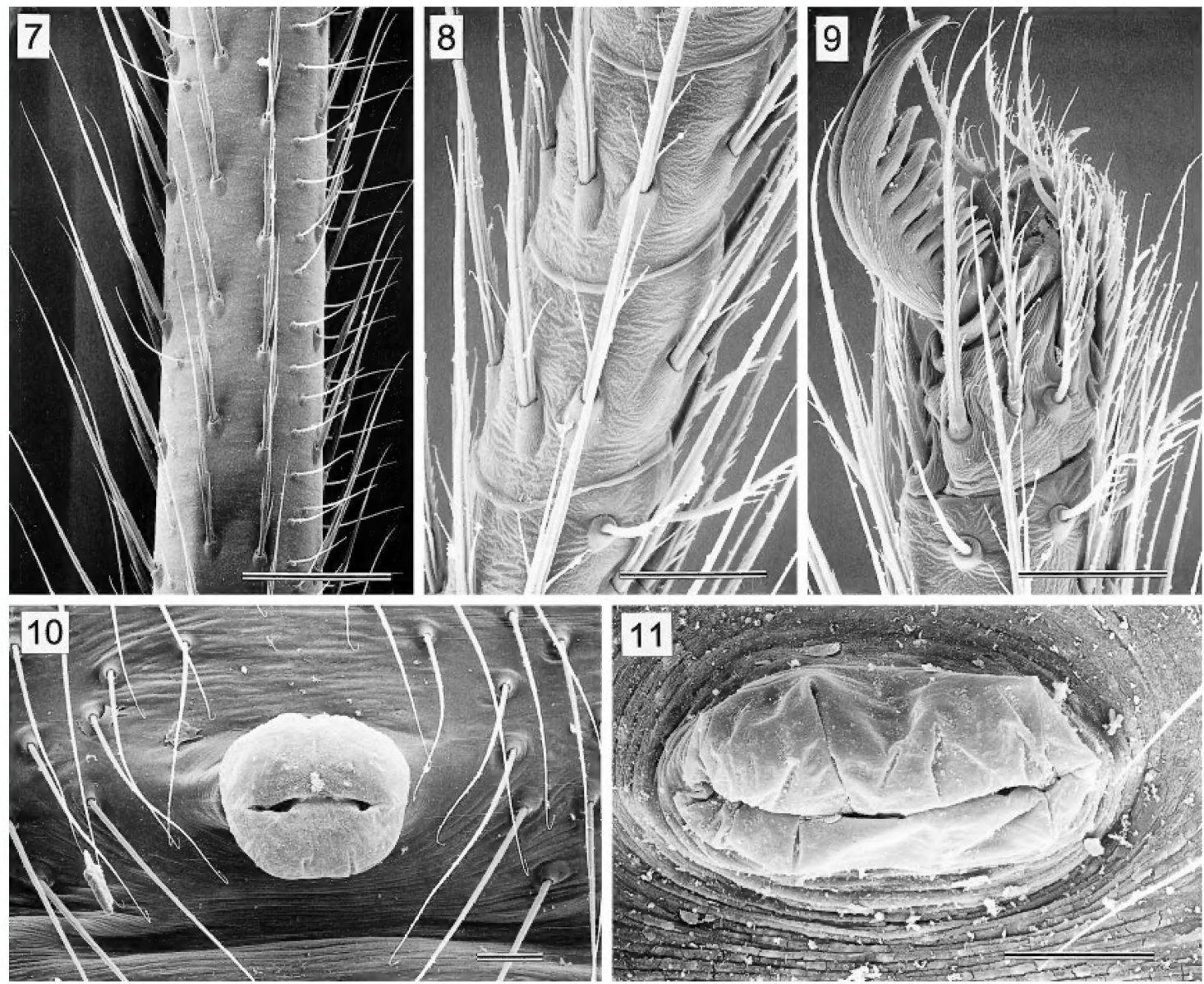

Figs. 7-11. SEM photographs of C. antraia (7-10) and C. nuriae (11). 7. Male tibia 1, showing vertical hairs (most on right side). 8. Male tarsus 1, showing distinct pseudosegmentation. 9. Male tarsal claws, leg 1. 10, 11. Male gonopores. Scale lines: $150 \mu \mathrm{m}(7), 30 \mu \mathrm{m}(8-11)$.

genera are extremely different in almost every aspect. The same is true of three other South American genera that share the high density of vertical hairs on the male tibiae (Pomboa Huber, Pisaboa Huber, Waunana Huber). Cladistic analysis did not produce a more satisfying result. Adding Ciboneya nuriae to the matrix in Huber (2001) (see codings in appendix 1) and using the same methods as previously (i.e., the same computer programs and the same criteria for tree selection as in Huber, 2001) resulted in numerous most parsimonious cladograms. All of these had Ciboneya in the New World clade, but apart from that, the position was extremely variable. Remarkably, however, in most topologies Ciboneya was very basal. In sum, even though the sister group remains obscure, the closest relatives are clearly South and Central American.

NATURAL History: Three of the four species have been found in the leaf litter and under rocks in humid forests. The type species, $C$. nuriae, was also collected under rocks in caves, but it shows no morphological adaptations to cave life and might just enter caves occasionally (and survive there when the forests outside are destroyed). The fourth species, $C$. antraia, has been found only within caves, shows morphological adaptations (pale color, long legs), and is the only species where a few observations on its biology have been made (see species description below).

Distribution: Ciboneya seems to be restricted to western Cuba (Pinar del Rio and 

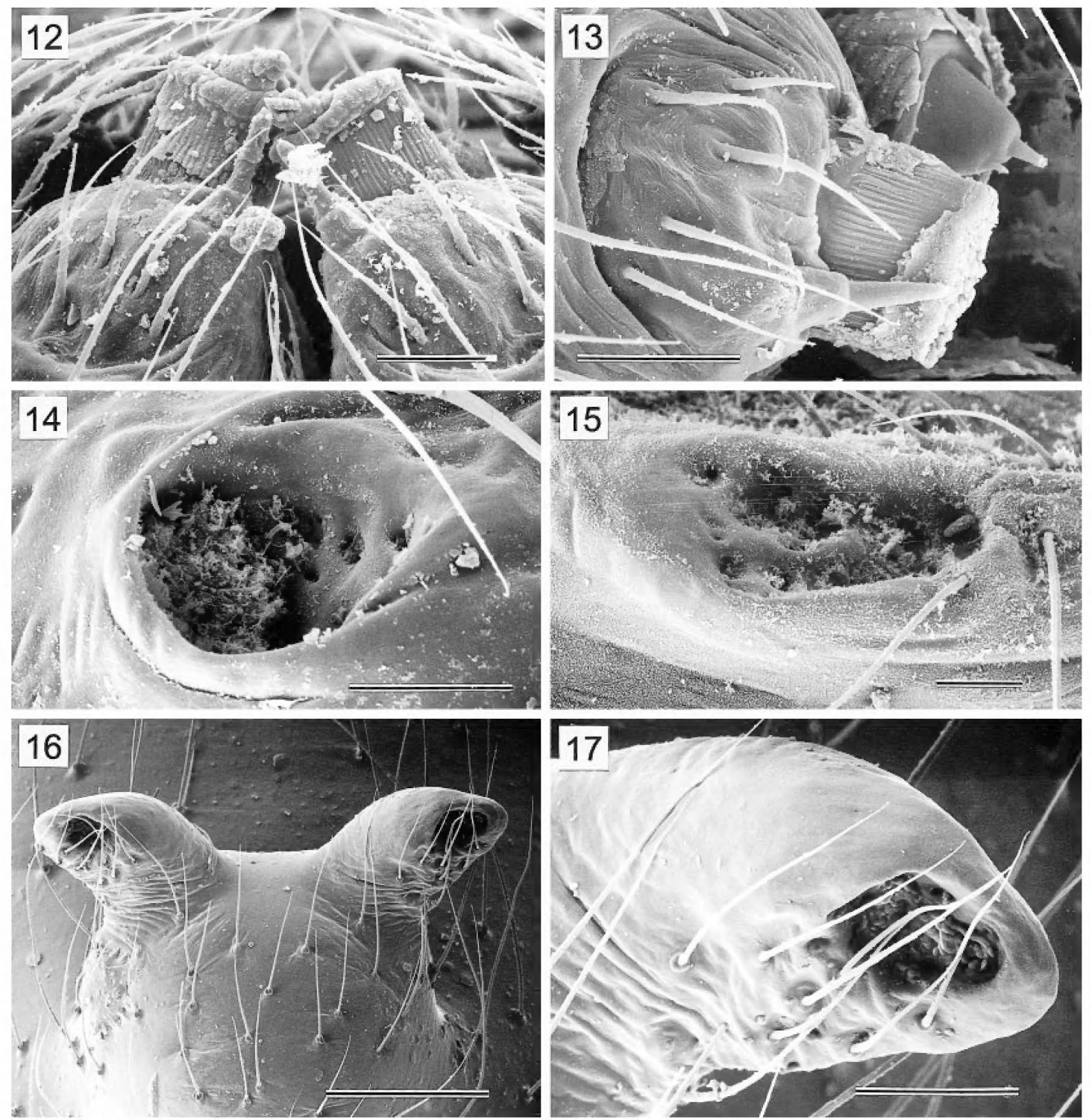

Figs. 12-17. SEM photographs of C. parva (12), C. nuriae $(13,15), C$. odilere (14), and C. antraia $(16,17) .12$. Female anterior lateral spinnerets. 13. Male left anterior lateral and posterior median (upper right corner) spinnerets. 14, 15. Pockets on epigynum. 16. Anterior apophyses on the epigynum of a microgyne. 17. Detail of figure 16, showing pocket at tip of apophysis. Scale lines: $150 \mu \mathrm{m}(16), 50$ $\mu \mathrm{m}$ (17), $20 \mu \mathrm{m}(12-15)$.

La Habana provinces; map 1). It may have gone unnoticed in other parts, but repeated collection trips to the east have not turned up a single individual. In fact, during our 1999 trip we visited the Escambray in central Cuba to search specifically for Ciboneya, but we did not find it.
Composition: Only the four species described below are known to us.

\section{Ciboneya nuriae, new species}

Figures 3, 11, 13, 15, 18-37

TyPES: Male holotype, five female paratypes, and four juveniles from Cueva del Tu- 


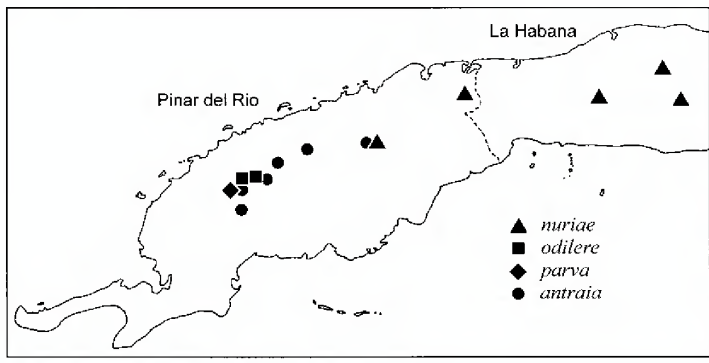

Map 1. Map of Western Cuba showing the known geographic distribution of Ciboneya.

nel, La Salud, Prov. La Habana, Cuba; Nov. 25, 1995 (A. Pérez González and N. Torres), under stone in dark zone of cave, in IES. One male and one female paratypes, same collection data, in AMNH.

ETYMOLOGY: Named for the second collector, Nuria Torres.

DiaGNOSIS: Distinguished from congeners by the rounded, hook-shaped apophysis proximally and the short apophysis accompanying the spine distally on the procursus (both on prolateral side; figs. 27, 28) and by the single short projection distally on the bulb (ventral side; figs. 29, 30).

MALE (holotype): Total length 2.6, carapace width 1.29. Leg 1: $12.9(3.2+0.5+$ $3.3+4.4+1.5$ ), tibia $2: 2.2$, tibia $3: 2.0$, tibia $4: 3.5$; tibia $11 / \mathrm{d}: 19$. Habitus and prosoma shape as in figs. 18-20. Carapace ochre with slightly darker Y-mark in thoracic and cephalic grooves; lateral margins also slightly darker. Ocular area slightly darker than carapace; distance PME-PME 0.125; diameter PME 0.085; distance PME-ALE 0.045; diameter AME 0.025. Sternum wide (fig. 21), monochromous ochre; labium light brown. Chelicerae light brown, with apophyses on fangs pointing obliquely toward the front (figs. 18, 22). Distance between tips of fang apophyses 0.23 . Palps as in figs. 23 and 24 , mostly ochre, coxae light brown, procursus with brown and black structures. Procursus with distinctive hook-shaped apophysis proximally and short apophysis accompanying spine distally on procursus (figs. 23, 27). Bulb with single projection distally on embolar division (fig. 29). Procursus length (fig. 27): 1.23. Legs ochre like prosoma, without rings; without spines and curved hairs, but with many vertical hairs on tibiae and meta- tarsi (especially on legs 1, much less on others); retrolateral trichobothrium of tibia 1 at $31 \%$; tarsus 1 with about 20 distinct pseudosegments. Opisthosoma as in fig. 18, bluish gray, densely covered with large darker spots except ventrally; genital plate large, light brown; plate in front of spinnerets light brown.

VARIATION: The three other males from La Habana Province are very similar: carapace width 1.10-1.29; tibia 1 length $2.9-3.3$; procursus length 1.03-1.26; distance between tips of fang apophyses $0.21-0.26$. The single male from Pinar del Rio, Sierra del Rosario, is significantly larger (carapace width 1.40; tibia 1: 5.07), even with respect to genitalic characters that are usually less variable (procursus length 1.45; distance between fang apophyses 0.39). Nevertheless, it is assigned to the present species because the shapes of chelicerae, procursus, and bulb seem to be identical (figs. 25, 26, 28, 30).

Female: In general similar to male. La Habana province $(\mathrm{N}=12)$ : tibia $1: 2.5-3.5(\overline{\mathrm{x}}$ $=3.18)$, carapace width $1.1-1.4(\overline{\mathrm{x}}=1.32)$. Epigynum as in figs. 31 and 35 ; varying only slightly in shape; distance between pockets $0.18-0.25(\overline{\mathrm{x}}=0.21)$ (inner margins), 0.27$0.35(\bar{x}=0.29)$ (outer margins). Dorsal view as in fig. 34.

The females from Pinar del Rio differ significantly and seem to show a similar kind of genitalic dimorphism as does $C$. antraia, but the sample size in this case is much too small. Two females from Sierra del Rosario are large (carapace width $1.45,1.52$; tibia 1: $4.6,4.6)$ and have an epigynum as shown in figs. 32 and 36; distance between pockets: $0.28,0.29$ (inner margins), $0.37,0.41$ (outer margins); four females from Sierra del Rosario and the single female from Sierra de Guira are small (carapace width: 1.13-1.24; tibia 1: 2.6-3.4) and have an epigynum as shown in figs. 33 and 37 . However, the distance between the pockets is hardly different: 0.28-0.32 (inner margins), 0.37-0.45 (outer margins). These females are all tentatively grouped into a single species under the assumption that it shows either a similar case of genitalic polymorphism as does $C$. antraia, or an unusual variation in epigynum shape.

DISTRIBUTION: Known from three localities 


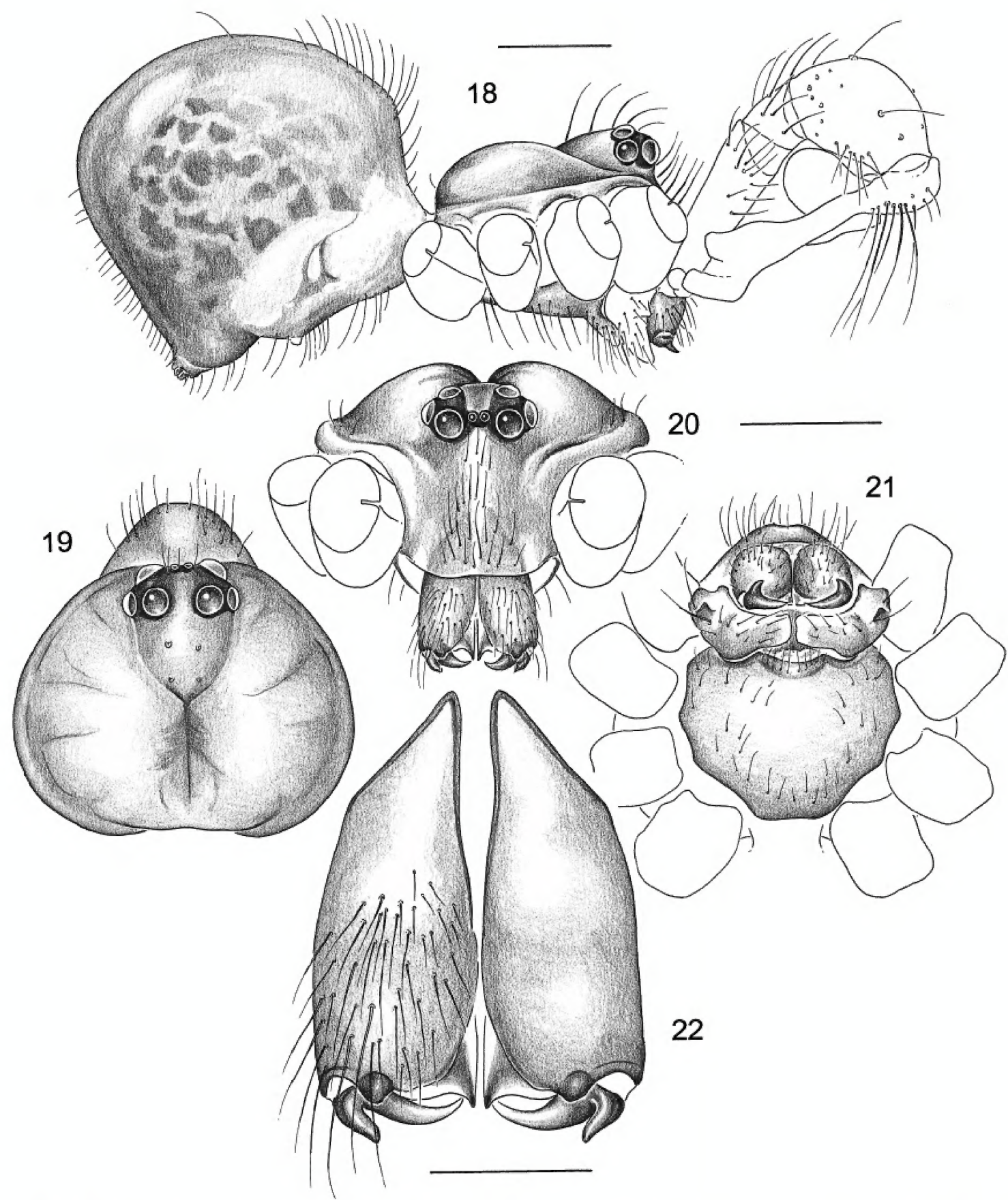

Figs. 18-22. C. nuriae, male from Tapaste. 18. Habitus. 19-21. Prosoma in dorsal, frontal, and ventral views. 22. Chelicerae, frontal view. Scale lines: $0.5 \mathrm{~mm}(18-21), 0.2 \mathrm{~mm}(22)$.

in La Habana Province (at least two of which are caves) and from Sierra del Rosario (forest floor) and Sierra de Guira in Pinar del Rio Province (map 1).
MATERIAl EXAMINED: CUBA: La Habana: La Salud, Cueva del Tunel: Types above; Tapaste, Cueva del Indio, Sept. 1994 (A. Pérez González), 2 đิ 4 ㅇ, in IES; “Candela, P. Ber- 


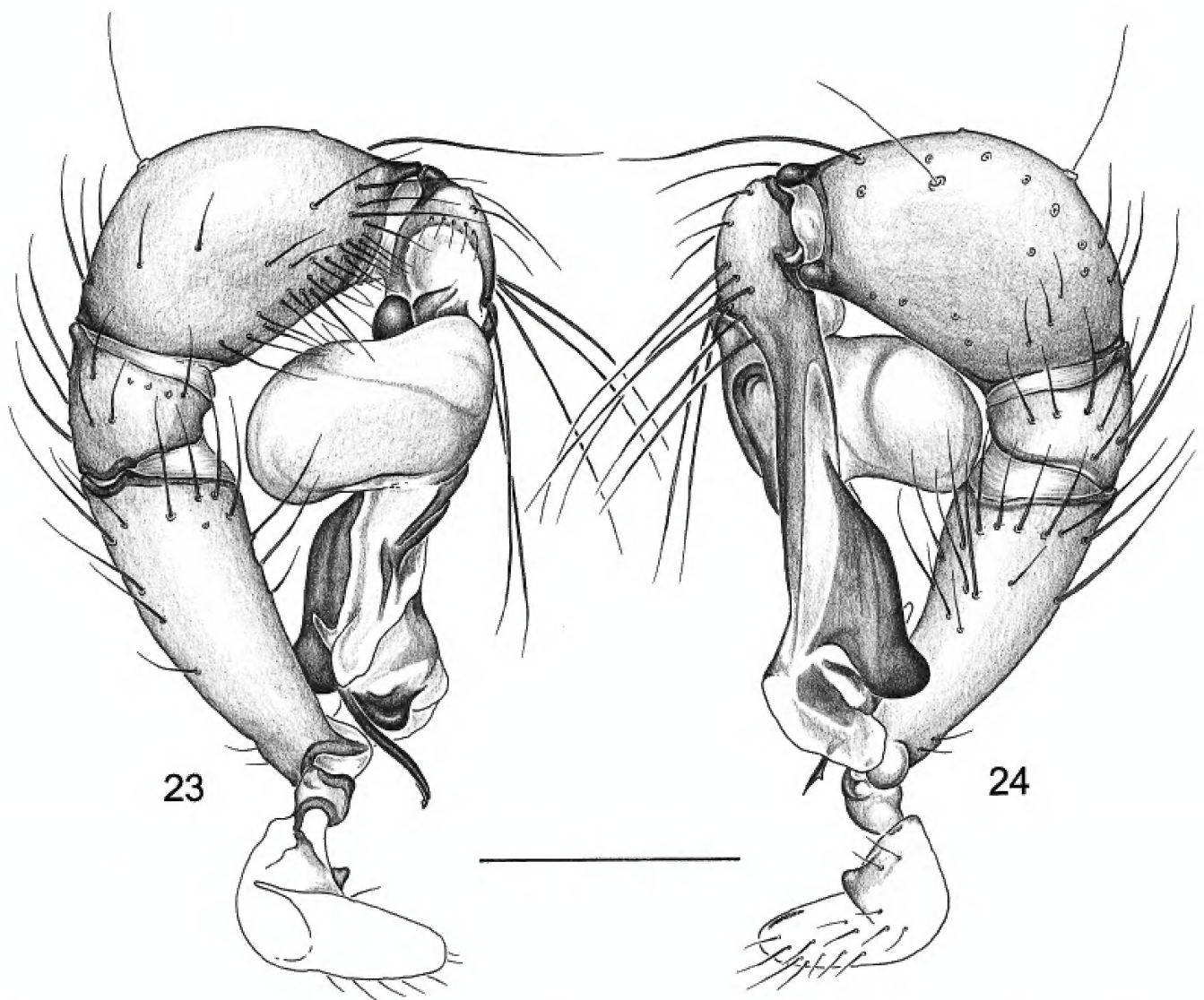

Figs. 23, 24. C. nuriae, male from Tapaste. Left palp in prolateral (23) and retrolateral (24) views. Scale line: $0.5 \mathrm{~mm}$.

mudez, Sherman C. Bishop Collection" (probably $22^{\circ} 53^{\prime} \mathrm{N}, 82^{\circ} 04^{\prime} \mathrm{W}$ ), no further data, 29 , in AMNH. Pinar del Rio: Sierra del Rosario, Loma del Mulo, Nov. 1, 1999 (A. Pérez González, B. A. Huber), 10 đ 695 juveniles, in IES; Sierra de Guira, Los Pinos Parque, Jan. 1995 (L. F. Armas), 1 , , in IES.

\section{Ciboneya odilere, new species}

Figures 14, 38-49

TYPES: Male holotype, one female paratype, and one juvenile from Ceja de Francisco, Prov. Pinar del Rio, Cuba; Mar. 19, 1994 (A. Pérez González), pine forest; in IES. One male paratype, same collection data, in AMNH.

ETYMOLOGY: The species name is a noun in apposition, referring to Odilere, a beautiful bird in Cuban oral tradition. The envious oth- er birds spattered her with dirt of all colors, making her even more beautiful.

Diagnosis: Closely related with $C$. parva, distinguished by the procursus (narrow and straight, with smaller ventrodistal hump, fig. 41 ), the more anterior position of the pockets on the epigynum (figs. 44, 46), and the longer legs. Distinguished from the two other known species by the pair of distal processes on the embolar division of the bulb (figs. 42, 43) and by the projection accompanying the distal spine on the procursus (fig. 41).

MaLE (holotype): Total length 2.5, carapace width 1.23. Leg 1: $13.0(3.3+0.5+$ $3.3+4.7+1.2$ ), tibia $2: 2.1$, tibia $3: 1.9$, tibia 4 missing; tibia 1 1/d: 23 . Habitus, prosoma shape, and colors as in $C$. nuriae (cf. figs. 18-20); distance PME-PME 0.135; diameter PME 0.095; distance PME-ALE 0.065; diameter AME 0.025. Apophyses on 


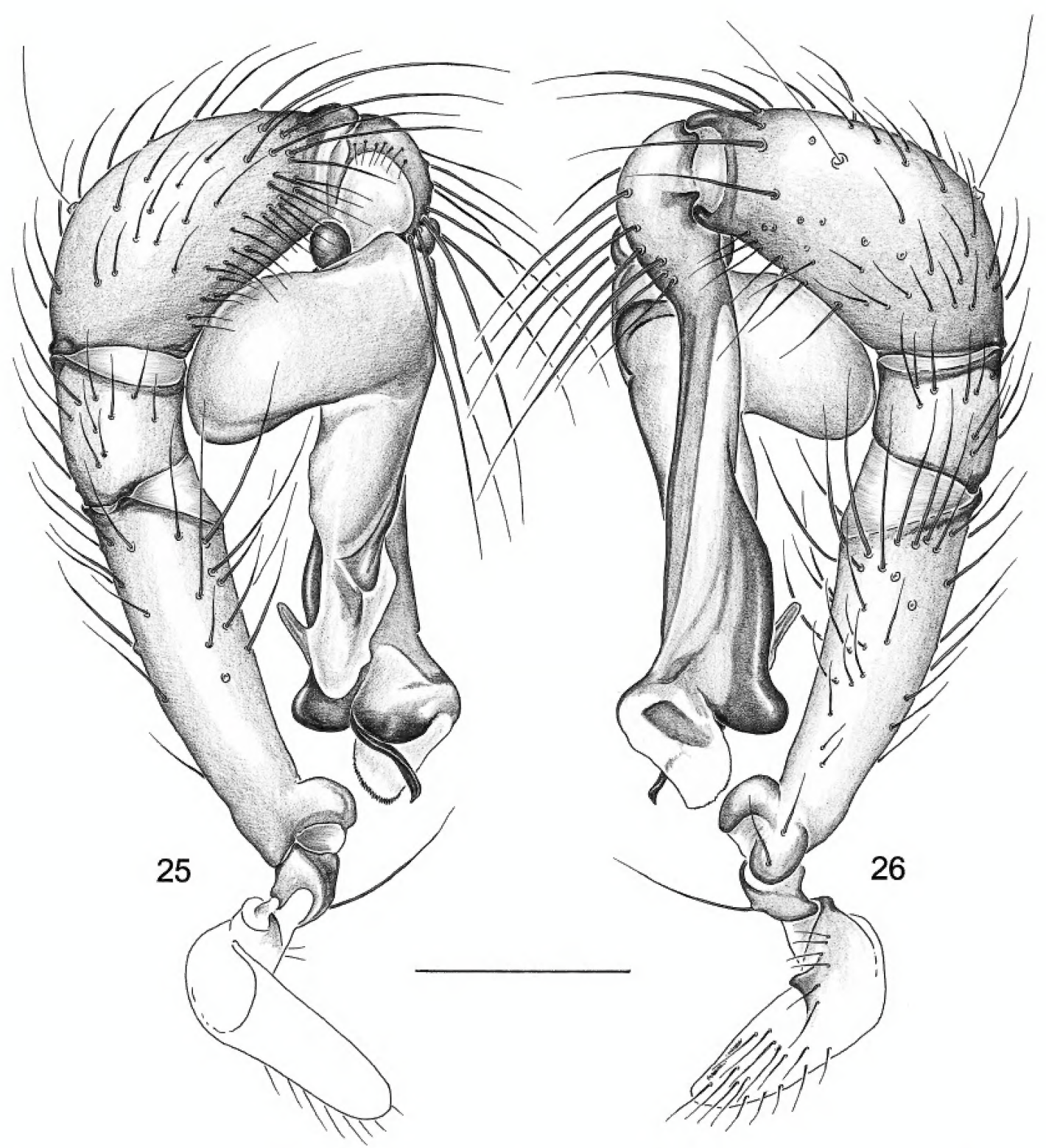

Figs. 25, 26. C. nuriae, male from Sierra del Rosario. Left palp in prolateral (25) and retrolateral (26) views. Scale line: $0.5 \mathrm{~mm}$.

cheliceral fangs pointing downward (fig. 40). Distance between tips of fang apophyses 0.29 . Palps as in figs. 38 and 39 , colors as in C. nuriae; femur proximally without retrolateral hump or apophysis; apophysis proximally on procursus not hook-shaped (fig. $41)$; embolar division of bulb with two projections, dorsal one rounded, ventral one distinctively long and pointed (fig. 42). Procur- sus length (fig. 41): 0.83. Legs in general as in $C$. nuriae; retrolateral trichobothrium of tibia 1 at 28\%; tarsus 1 with about 23-24 distinct pseudosegments. Opisthosoma shape and colors as in C. nuriae (cf. fig. 18).

VARIATION: Male paratype: carapace width 1.16; tibia 1 : 3.3 ; tibia $4: 3.5$; procursus length 0.86 ; distance between tips of fang apophyses 0.25 . The male collected near the 


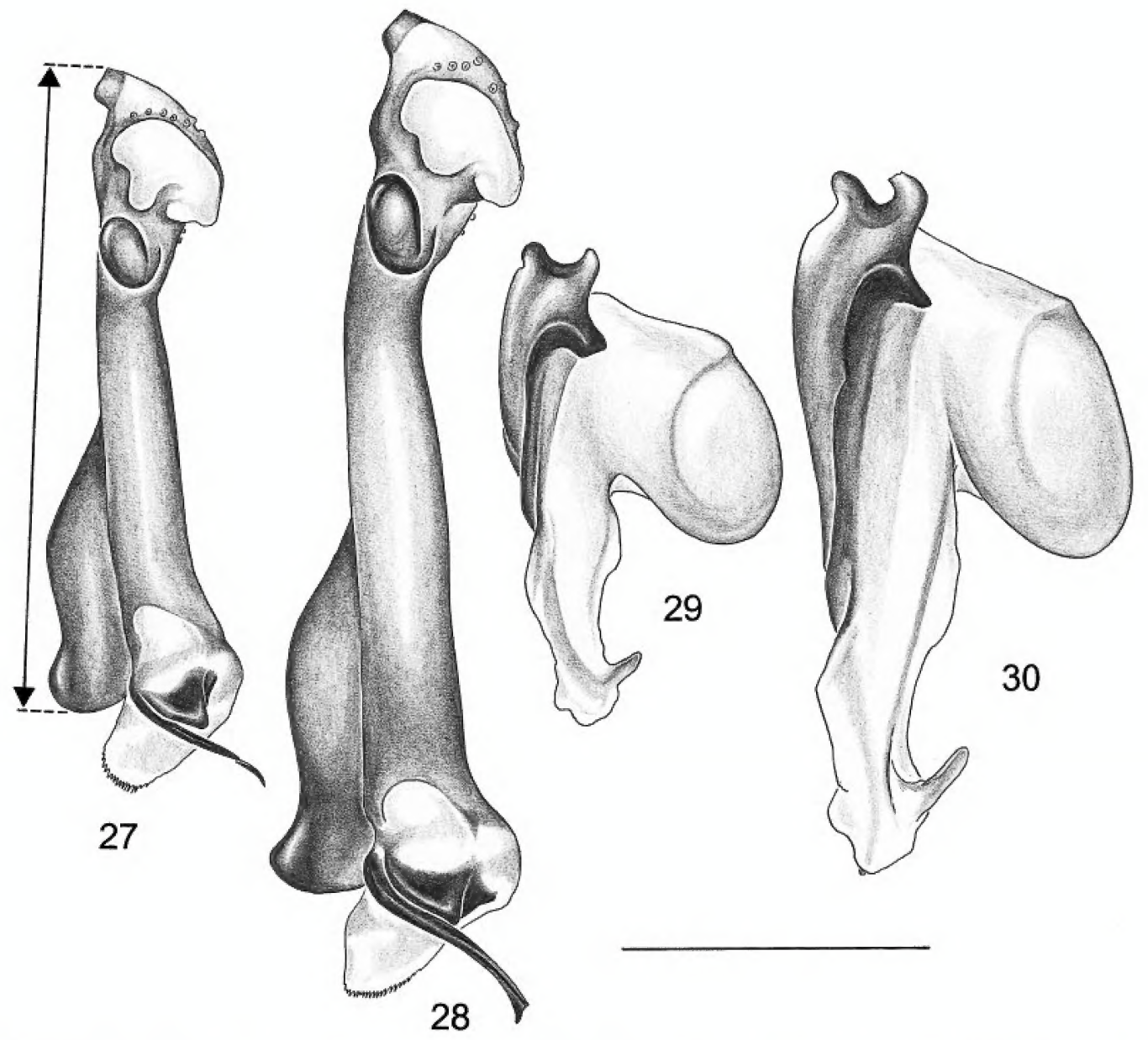

Figs. 27-30. C. nuriae, males from Tapaste $(27,29)$ and from Sierra del Rosario (28, 30). $27,28$. Left procursi, prolateral views (bar $=$ "procursus length"). 29, 30. Left genital bulbs, retrolateral views. Scale lines: $0.5 \mathrm{~mm}$.

type locality in Oct. 1999 has a distinctly longer dorsal projection on the bulb (fig. 43), and the hump marked with an arrow in fig. 41 is slightly more developed; carapace width 1.32 ; tibia 1 : 4.0 ; tibia $4: 4.3$; procursus length 0.83 ; distance between tips of fang apophyses 0.26 .

Female: In general similar to male. Female paratype: carapace width 1.16 , tibia 1 missing. Epigynum as in figs. 44 and 48; distance between pockets 0.41 (inner margins), 0.49 (outer margins); dorsal view as in fig. 45.

Most other females collected in the area (Sierra de Mesa, Sierra de Gramales) have a quite different epigynum that is longer fron- tally and has the pockets closer together (figs. $46,47,49)(\mathrm{N}=13)$ : carapace width $1.10-1.42(\overline{\mathrm{x}}=1.29)$, tibia $1: 3.6-4.5(\overline{\mathrm{x}}=$ $3.95)$; distance between pockets: $0.21-0.29$ $(\overline{\mathrm{x}}=0.25)$ (inner margins), 0.28-0.36 $(\overline{\mathrm{x}}=$ 0.31) (outer margins).

Distribution: Known from Sierra de Mesa and Sierra de Gramales in Pinar del Rio Province (map 1).

Material Examined: CUBA: Pinar del Rio: Ceja de Francisco: Types above; Sierra de Mesa, Ceja de Francisco, Oct. 28, 1999 (A. Pérez González and B. A. Huber), 10 3 ㅇ 1 juvenile, in leaf litter and under stones, in IES; same locality and collectors, Oct. 29, 1999, 2 q in leaf litter and under rocks, in 


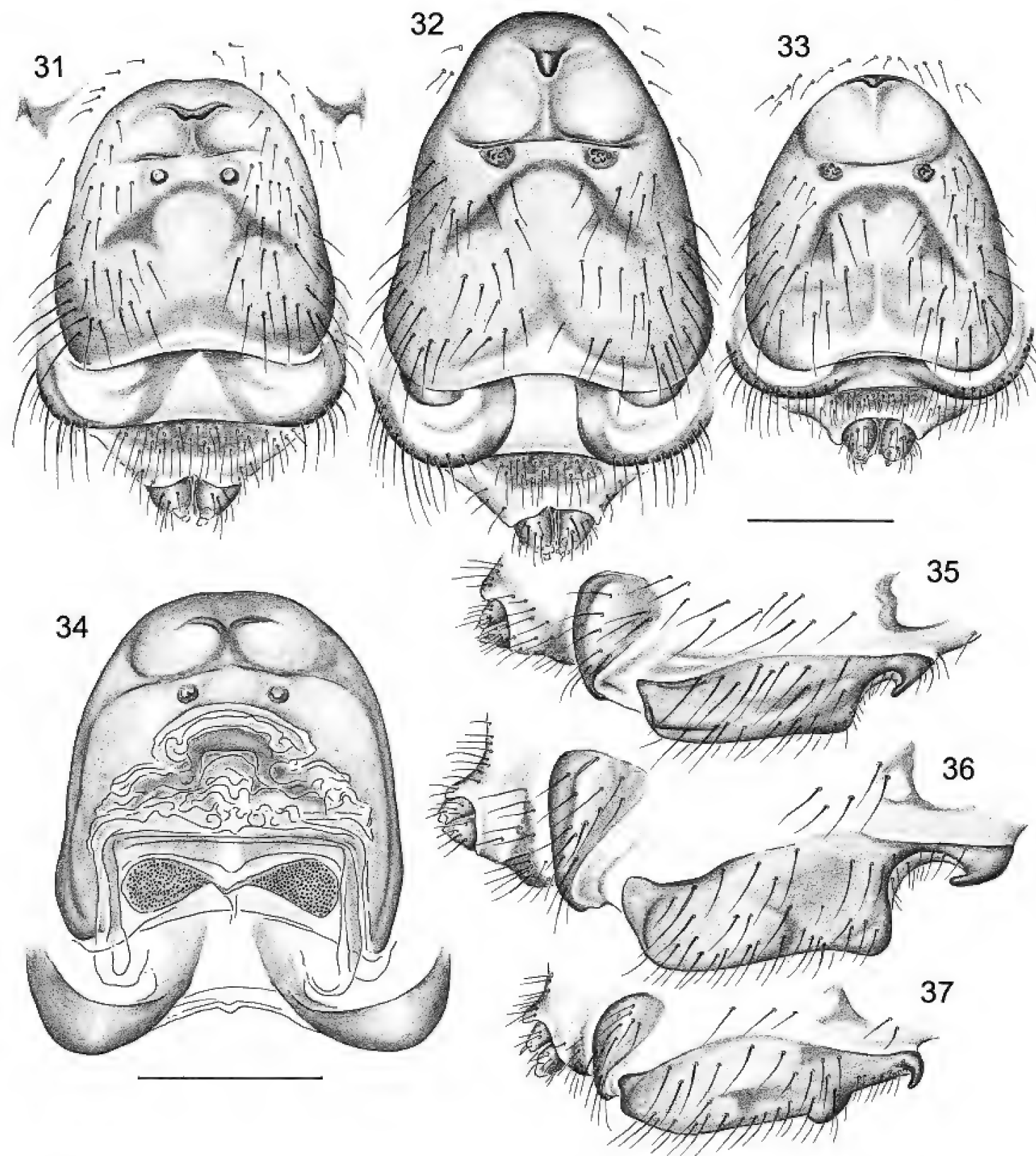

Figs. 31-37. C. nuriae, females from La Salud $(31,34-35)$ and from Sierra del Rosario $(32,33$, 36, 37). 31-33. Epignya, ventral views. 34. Epigynum, dorsal view. 35-37. Epigyna, lateral views. Scale lines: $0.5 \mathrm{~mm}$ (ventral and lateral views drawn to same scale).

IES; Sierra de Mesa, July 8, 1999 (A. Pérez González), 2 q 1 juvenile, in IES; Sierra de Gramales, Hoyo Colorado, Sept. 1999 (A. Pérez González), 5 q 2 juveniles, in IES; Sierra de Gramales, no further data, $1 q$, in IES.
Ciboneya parva, new species

Figures 12, 50-57

TYPES: Male holotype and four female paratypes from Ceja de Francisco, Sierra de 


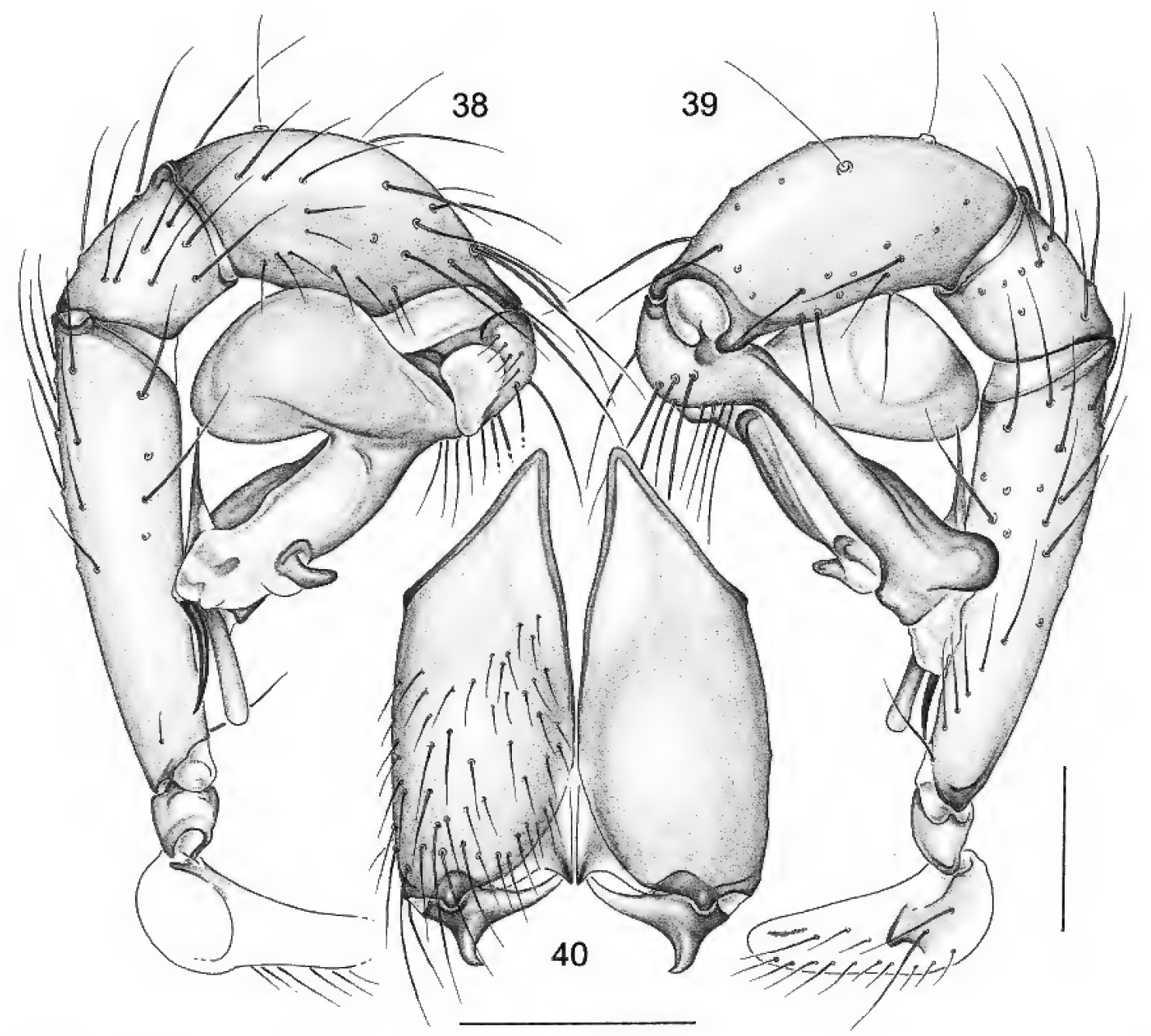

Figs. 38-40. C. odilere, male. 38, 39. Left palp, prolateral (38) and retrolateral (39) views. 40. Chelicerae, frontal view. Scale lines: $0.3 \mathrm{~mm}$.

Mesa, Pinar del Rio Province, Cuba; Oct. 28, 1999 (B. A. Huber and A. Pérez González), in leaf litter and under stones; in IES. One female paratype, same collection data, in AMNH

ETYMology: The species name is an adjective (Latin parvus, "small"), referring to the small size of this species compared with known congeners.

Diagnosis: Closely related to $C$. odilere, distinguished by the procursus (wider and more curved, with prominent ventrodistal hump, fig. 53), the more posterior position of the pockets on the epigynum (fig. 55), and the shorter legs. Distinguished from the two other known species by the pair of distal processes on the embolar division of the bulb (fig. 54) and by the projection accompanying the distal spine on the procursus (fig. 53).

MALE (holotype): Total length 2.3, carapace width 1.10. Leg 1: $8.4(2.1+0.4+2.2$ $+2.7+1.0$ ), tibia $2: 1.5$, tibia $3: 1.3$, tibia 4: 2.4 ; tibia 1 1/d: 15 . Habitus, prosoma shape, and colors as in $C$. nuriae (cf. figs. 18-20), but sternum with large median ochre-gray mark; distance PME-PME 0.120; diameter PME 0.095; distance PME-ALE 0.055; diameter AME 0.025. Apophyses on cheliceral fangs pointing downward (fig. 52). Distance between tips of fang apophyses 


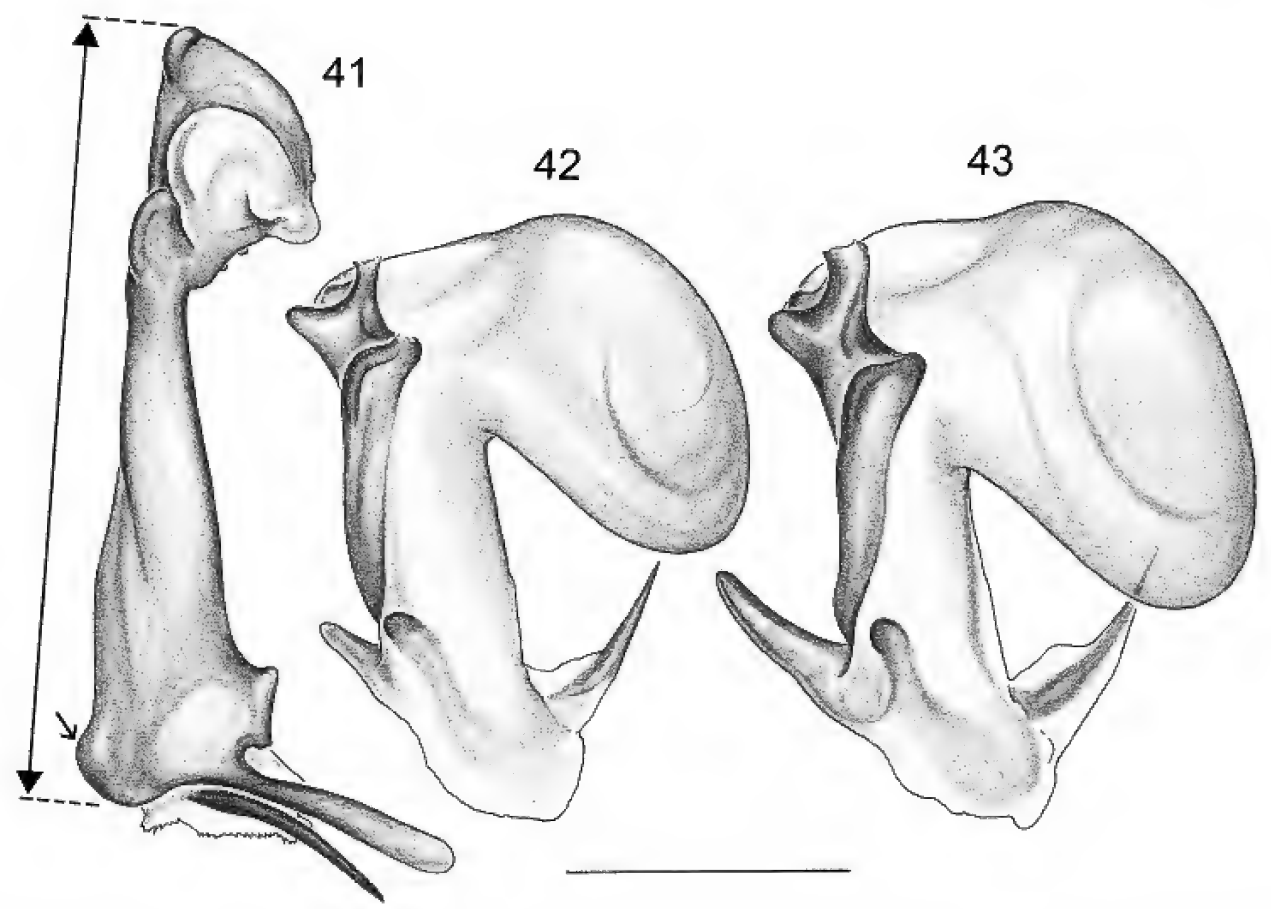

Figs. 41-43. C. odilere, male paratype $(41,42)$ and male from near type locality $(43)$. 41. Left procursus, prolateral view (bar = "procursus length"; arrow: this apophysis is developed more strongly in male from near type locality). 42, 43. Left bulbs, retrolateral views. Scale line: $0.3 \mathrm{~mm}(41-43)$.

0.22. Palps as in figs. 50 and 51 , colors as in C. nuriae; femur proximally with roundish retrolateral hump; apophysis proximally on procursus not hook-shaped (fig. 53); bulb with two projections of similar length (fig. 54). Legs as in C. nuriae; retrolateral trichobothrium of tibia 1 at $28 \%$; tarsus 1 with about 18 fairly distinct pseudosegments. Opisthosoma shape as in C. nuriae (cf. fig. 18), very dark greenish gray, densely covered with blackish spots except ventrally; genital plate large, brown; smaller plate in front of spinnerets.

FEMALE: In general similar to male, but prosoma darker and sternum uniformly brown. Paratypes $(\mathrm{N}=5)$ : carapace width $0.98-1.11(\overline{\mathrm{x}}=1.05)$; tibia $1: 1.86-2.13(\overline{\mathrm{x}}$ $=1.98)$. Epigynum as in figs. 55 and 56 , distance between pockets: $0.24-0.27(\overline{\mathrm{x}}=$ $0.26)$ (inner margins), $0.27-0.31(\overline{\mathrm{x}}=0.29)$ (outer margins); dorsal view as in fig. 57.

DistRIBUTION: Known only from type locality (map 1).

Material Examined: CUBA: Pinar del Rio: Ceja de Francisco: Types above.

\section{Ciboneya antraia, new species}

Figures 1, 2, 4-10, 16, 17, 58-76

Types: Male holotype, 10 male and 23 female paratypes from Cueva de la Lechuza, Ceja de Francisco, Prov. Pinar del Rio, Cuba; Oct. 28, 1999 (A. Pérez González and B. A. Huber), in ISB; $2 \star 2 q$ paratypes, same collection data, in $\mathrm{AMNH} ; 202 \%$ paratypes, same collection data, in collection BAH.

ETYMOLOGY: The species name is from the Greek antraios ("cave dwelling"), and refers to the fact that this species has been found only in caves.

Diagnosis: Easily distinguished from known congeners by the long projection distally on the procursus (figs. 62-64), the ventral apophysis proximally on the male palpal femur (figs. 62, 63), and the absence of projections distally on the bulb (fig. 65).

MALE (holotype): Total length 3.5, carapace width 1.71. Leg 1: $32.1(8.1+0.7+$ $8.7+12.1+2.5)$, tibia $2: 5.6$, tibia $3: 2.9$, tibia 4: 7.1 ; tibia $11 / \mathrm{d}$ : 57 . Habitus and prosoma shape as in figs. 58-60. Carapace 


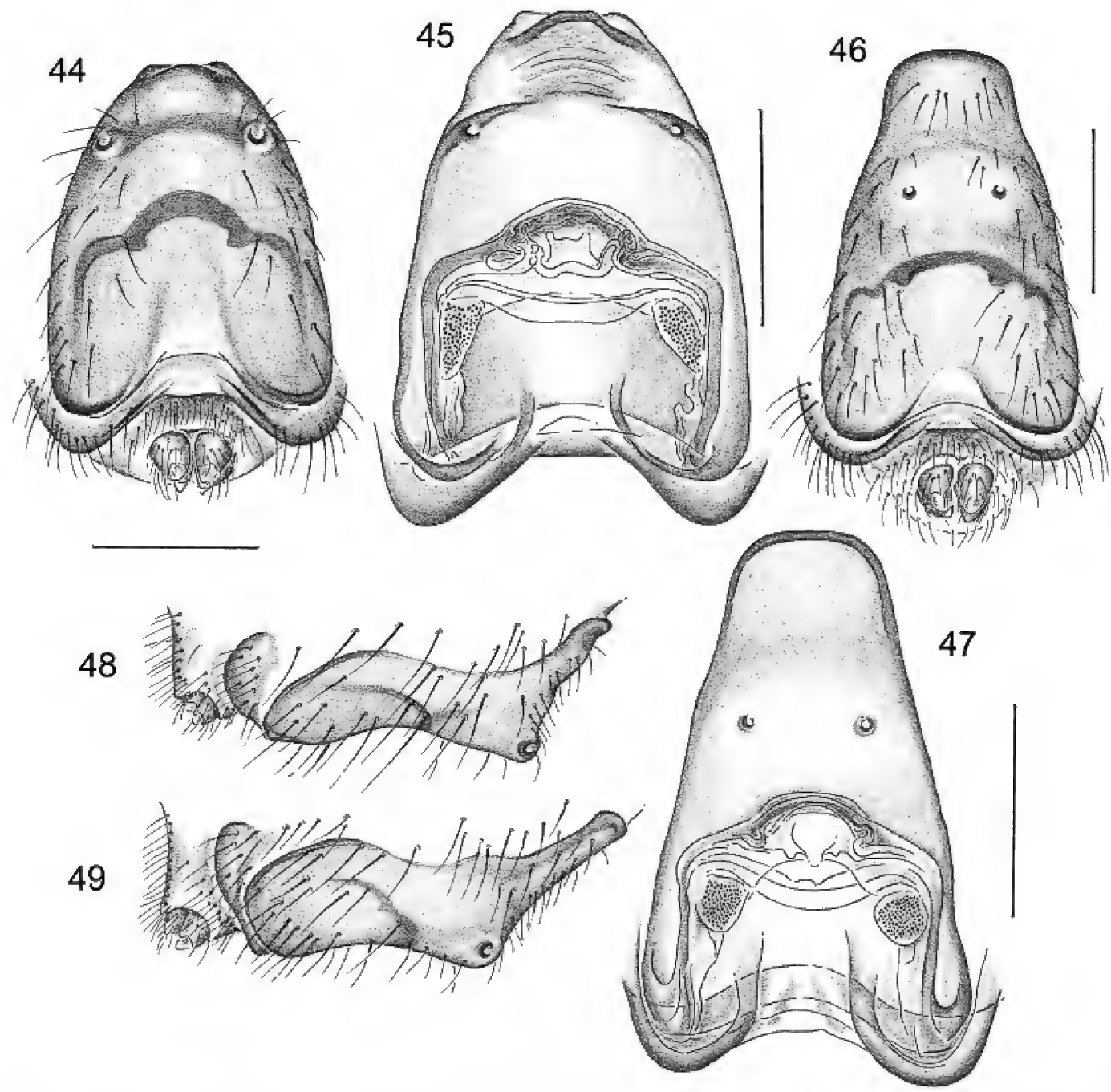

Figs. 44-49. C. odilere, female paratype $(44,45,48)$ and female from near type locality $(46,47$, 49). 44, 46. Epigyna, ventral views. 45, 47. Epigyna, dorsal views. 48, 49. Epigyna, lateral views. Scale lines: $0.5 \mathrm{~mm}$ (ventral and lateral views drawn to same scale).

whitish ochre with darker median line in thoracic groove and larger V-mark behind ocular area. Ocular area light brown; distance PME-PME 0.215; diameter PME 0.080; distance PME-ALE 0.040; diameter AME 0.035. Sternum shape as in $C$. nuriae (cf. fig. 21), monochromous light brown. Chelicerae light brown; apophyses on fangs pointing downwards (figs. 58,61). Distance between tips of fang apophyses 0.37 . Palps as in figs. 62 and 63 , mostly ochre to light brown; procursus with brown and black structures. Procursus without hook-shaped apophysis proximally, with black spine and distinctive long projection distally (fig. 64). Bulb without any distinct projections (fig. 65). Palpal femur length (fig. 63) 1.37; procursus length (fig. 64) 0.93. Legs ochre to light brown, without rings; without spines, with curved hairs on metatarsi 1 and 2, with many vertical hairs on tibiae and metatarsi (especially on legs 1 and 2, much less on others); retrolateral trichobothrium of tibia 1 at 24\%; tarsus 1 with about 30 distinct pseudosegments. Opisthosoma as in fig. 58, monochromous ochre-gray with some white 


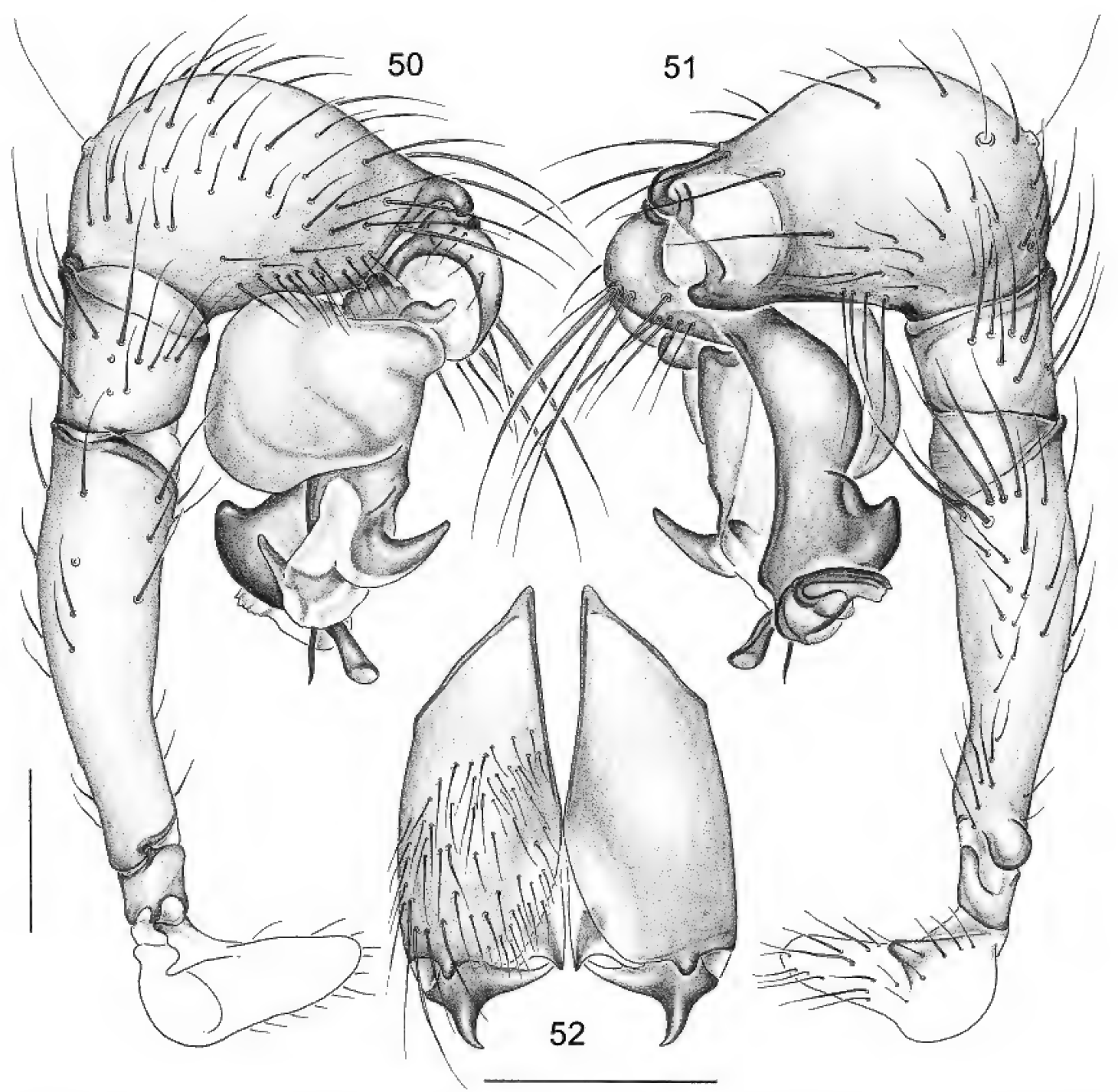

Figs. 50-52. C. parva, male holotype. 50, 51. Left palp, prolateral (50) and retrolateral (51) views. 52. Chelicerae, frontal view. Scale lines: $0.3 \mathrm{~mm}$.

spots; genital plate and plate in front of spinnerets slightly darker.

VARIATION: Males $(\mathrm{N}=19)$, in contrast to females, show only the usual continuous variation in size and no significant variation in shape: carapace width $1.45-1.81(\overline{\mathrm{x}}=1.63)$; tibia 1: $7.9-10.3(\overline{\mathrm{x}}=8.6)$; procursus length $0.87-1.00(\overline{\mathrm{x}}=0.94)$; palpal femur length $1.29-1.51(\overline{\mathrm{x}}=1.40)$; distance between tips of fang apophyses $0.33-0.39(\bar{x}=0.36)$. Some males with darker (light brown) frontal femora; some males with many ochre spots on opisthosoma, except ventrally.
FEMALE: In general similar to male, but with few vertical hairs on legs. Most characters show continuous range of size variation. Carapace width $(\mathrm{N}=35)$ 1.13-1.74 $(\overline{\mathrm{x}}$ $=1.43)$; tibia $1(\mathrm{~N}=32) 5.2-10.4(\overline{\mathrm{x}}=6.9)$. Epigynum, however, dimorphic, with "longtype" (figs. 66, 68) and "short-type" (figs. $67,69)$. Entire epigynum sclerotized (i.e., the two types are definite end-products and cannot be converted into each other in mature females by bending the frontal part back or forth). Females with long-type epigynum will hereafter be called "macrogynes", fe- 


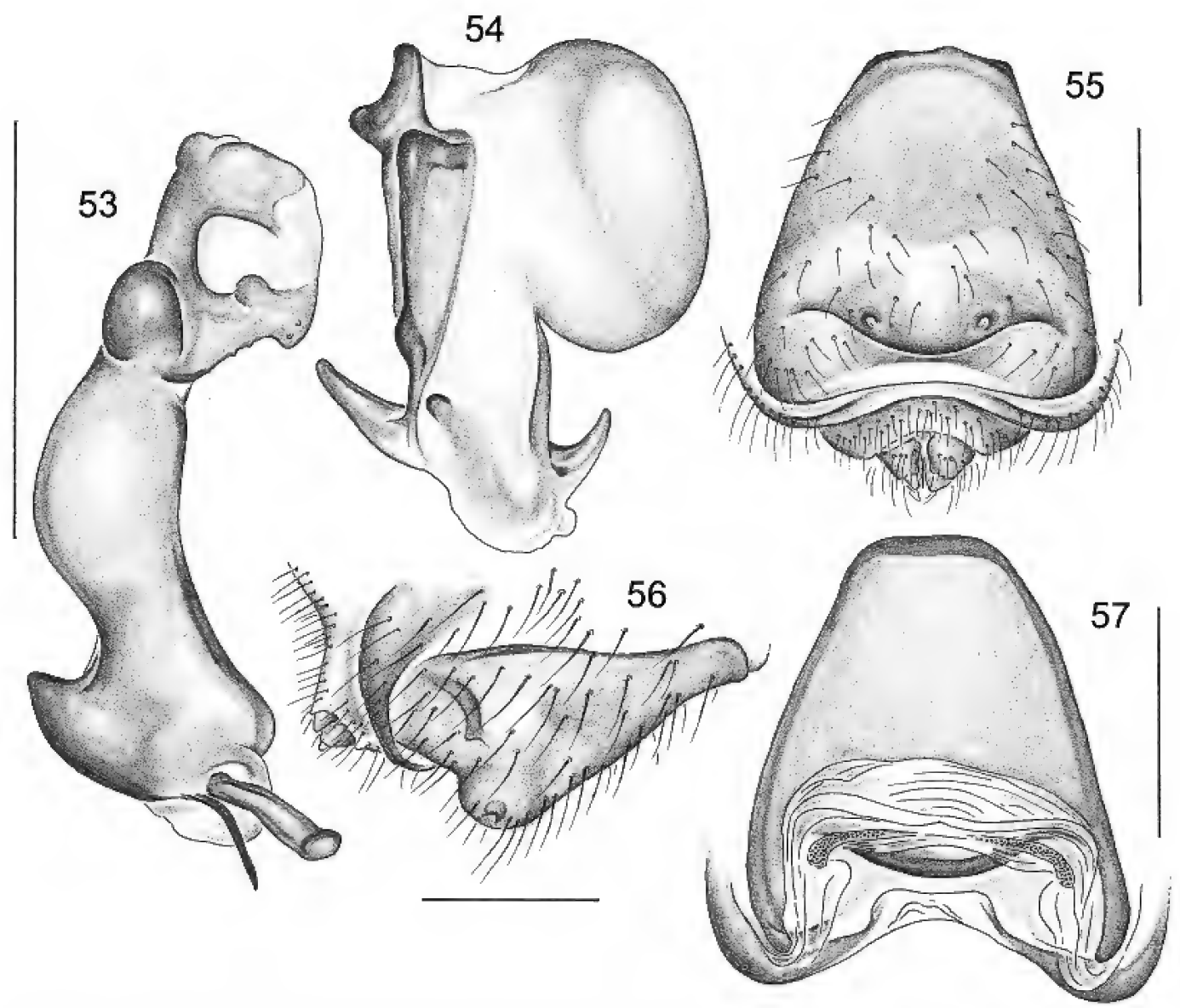

Figs. 53-57. C. parva, male holotype and female paratype. 53. Left procursus, prolateral view. 54. Left genital bulb, retrolateral view. 55, 56. Epigynum, ventral and lateral views. 57. Epigynum, dorsal view. Scale lines: $0.5 \mathrm{~mm}$.

males with short-type epigynum "microgynes" (terms borrowed from entomologists). Epigynum length (fig. 68) in macrogynes (N $=16)$ 1.51-2.12 ( $\overline{\mathrm{x}}=1.77)$; in microgynes $(\mathrm{N}=17) 0.33-0.80(\overline{\mathrm{x}}=0.61)$. Distance between pockets (fig. 66) not as clearly dimorphic: macrogynes: $0.24-0.40(\overline{\mathrm{x}}=0.33)$ (inner margins), 0.32-0.48 ( $\overline{\mathrm{x}}=0.43$ ) (outer margins); microgynes: $0.21-0.35(\overline{\mathrm{x}}=0.27)$ (inner margins), $0.32-0.44(\overline{\mathrm{x}}=0.37)$ (outer margins). One female of intermediate type (fig. 70): carapace width 1.39; tibia 1: 6.8; epigynum length 1.08, distance between pockets: 0.37 (inner margins), 0.45 (outer margins). Female internal genitalia similar in macro- and microgynes (figs. 71, 72).

Quantitative AnALYsis: To exclude possibly confusing interpopulation variation, the following quantitative analysis is restricted to the 15 males and 27 females collected on a single day in a single cave (the type material). Table 1 gives the basic statistics. Note the much higher coefficient of variation in female than in male characters and the extreme value in epigynum length. As figure 73 shows, all measured male characters vary fairly continuously and fall reasonably well into a normal distribution (a better fit is not expected with such a small sample size). Female characters tend to show a bimodal distribution (fig. 74). This bimodality is extreme in epigynum length, where the distribution is significantly different from normal (Kolmogorov-Smirnov, $\mathrm{P}=0.05$ ). Regressions of most characters on carapace width (all $\log _{10}$ transformed) are linear, with the exception of 


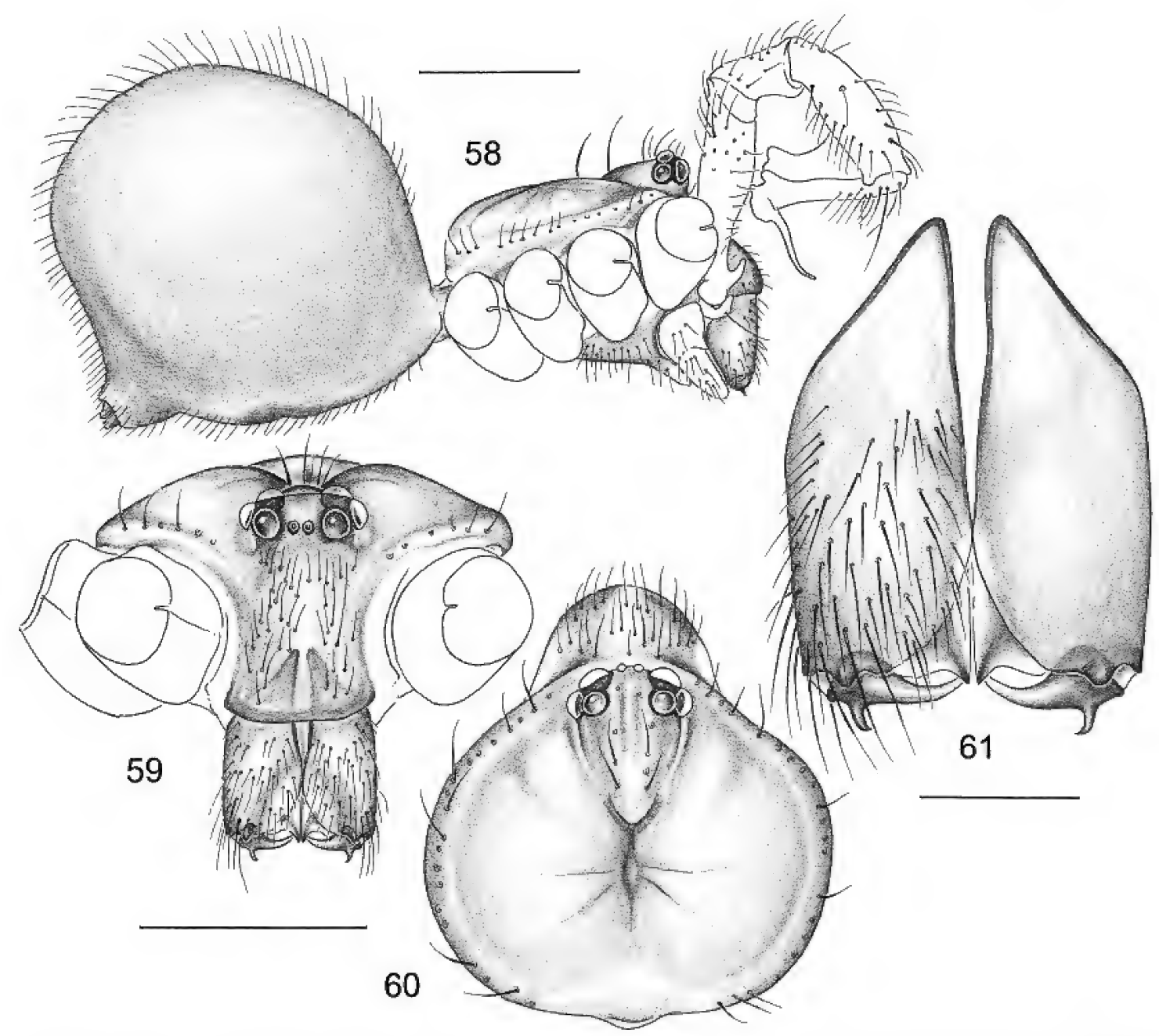

Figs. 58-61. C. antraia, male. 58. Habitus. 59, 60. Prosoma, frontal and dorsal views. 61. Chelicerae, frontal view. Scale lines: $1 \mathrm{~mm}(58-60), 0.3 \mathrm{~mm}(61)$.

epigynum length on carapace width, with the latter being decidedly sigmoidal (fig. 75).

Distribution: Known from several caves in Pinar del Rio Province (map 1).

NATURAL History: This species has been found only in caves, where the spiders build their webs either close to the ground or in crevices of lower sections of walls. When disturbed they do not vibrate their body, but dash off into some hole in the rock or over the cave floor (which makes them quite hard to catch, especially males). In captivity (15 males, 11 females, in containers of $6-8 \mathrm{~cm}$ diameter filled at the bottom with gypsum), the spiders built flimsy webs of no distinct shape. Drosophila flies hardly got entangled in the nonsticky silk of these webs, but the spiders were able to locate the flies immediately and loosely wrapped them before the victims could walk away on the web. While numerous attacks of this kind by females were observed, only once did a male attack while being observed. Females repeatedly produced egg-sacs in captivity $(\mathrm{N}=14)$; six females produced two successive egg-sacs each. The numbers of spiderlings emerging from egg-sacs of macrogynes were 24 and 29 , of microgynes $(\mathrm{N}=6)$ only $7-13$.

All attempts at observing the copulation of these spiders failed. Even though two of the females used were virgin (one macrogyne, one microgyne), and they were each con- 


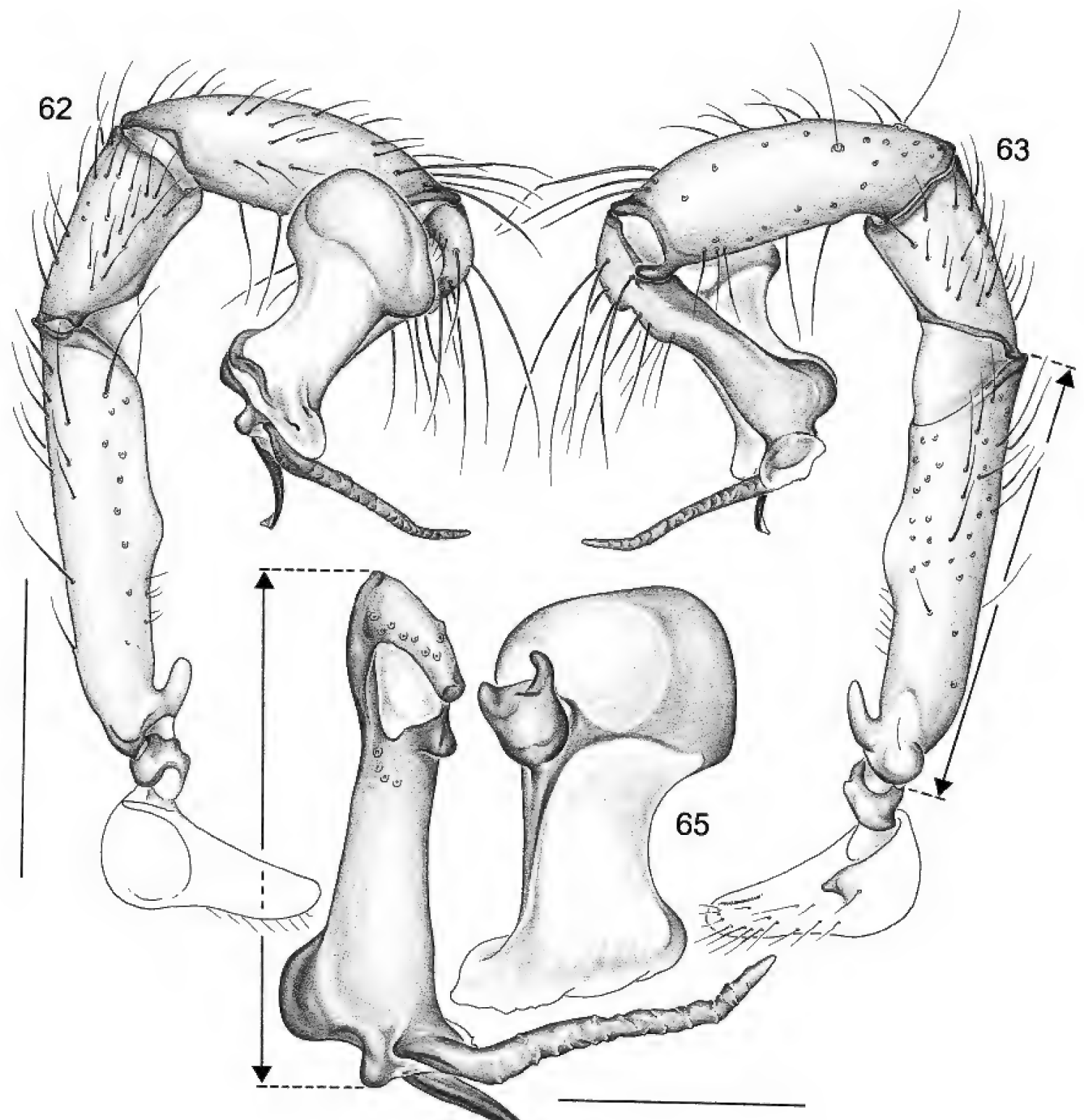

64

Figs. 62-65. C. antraia, male. 62, 63. Left palp, prolateral (62) and retrolateral (63) views (bar $=$ "palpal femur length"). 64. Left procursus, prolateral view (bar = "procursus length"). 65. Left genital bulb, retrolateral view. Scale lines: $1 \mathrm{~mm}(62,63), 0.5 \mathrm{~mm}(64,65)$.

fronted with four different males at different times, no male showed the least sign of courtship. This was no different under red light, nor in absolute darkness (with inter- mittent flashes of red light to check whether the position of the spiders had changed).

Spiderlings were reared in batches of siblings in larger containers filled at the bottom 

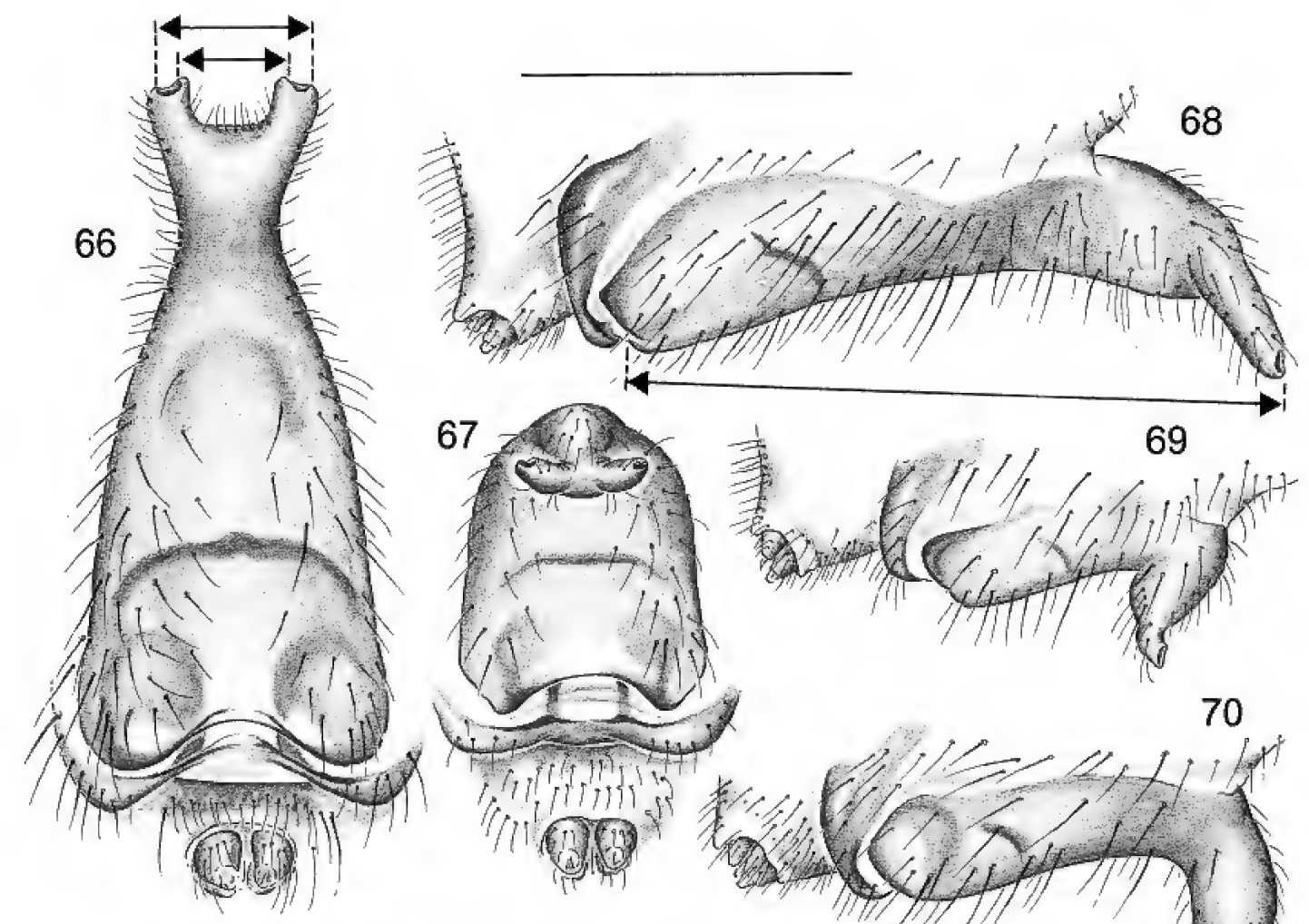

$x+10+1+1+14$
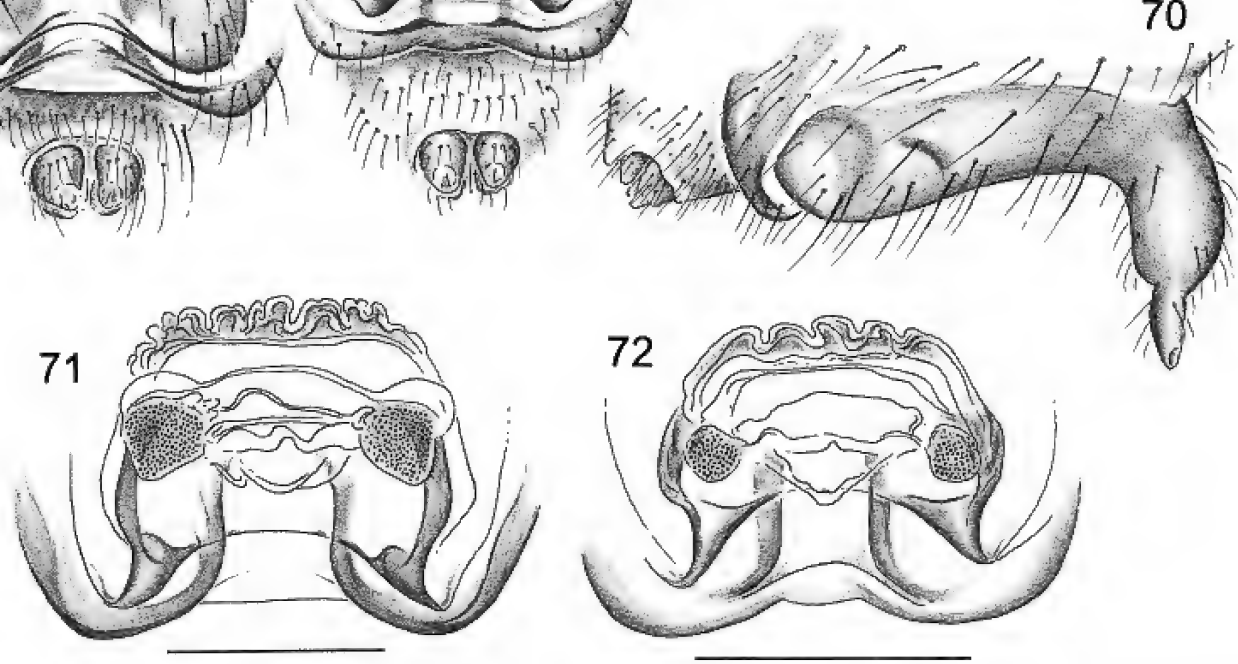

Figs. 66-72. C. antraia, female epigyna. 66, 67. Ventral views, macrogyne (66) and microgyne (67) (bars in fig. 66: distances between inner and outer margins of pockets). 68-70. Lateral views, macrogyne (68), microgyne (69), and intermediate morph (70) (bar in fig. 68: “epigynum length"). 71, 72. Dorsal views, macrogyne (71) and microgyne (72). Scale lines: $1 \mathrm{~mm}$ (66-70, all drawn to same scale), 0.5 $\mathrm{mm}(71,72)$.

with ordinary New York backyard soil, where they fed on the tiny arthropods emerging from the soil until they reached the size to capture Drosophila flies. Flies were reared in the same containers as the spiders, guaranteeing an almost continuous supply of food. Evidence for cannibalism was seen very rarely considering the partly crowded conditions (up to about 20 specimens in a 26 $\times 16 \times 8$-cm container). Time between emerging from the egg-sac and molting to maturity was about 17-27 weeks, but there were still some juveniles in the containers when the experiment had to be interrupted. Micro- and macrogyne mothers produced offspring of both morphs in the laboratory (fig. 76).

Material Examined: CUBA: Pinar del Rio: Ceja de Francisco, Cueva de la Lechuza: Types above; Sierra de Quemados, Gran 
TABLE 1

Measurements of $C$. antraia Specimens from the Type Locality ${ }^{a}$

\begin{tabular}{|c|c|c|c|c|c|}
\hline & $\mathrm{N}$ & Mean, $\mu \mathrm{m}$ & $\mathrm{SD}, \mu \mathrm{m}$ & Range, $\mu \mathrm{m}$ & $\mathrm{CV}^{\mathrm{b}}$ \\
\hline \multicolumn{6}{|l|}{ Male } \\
\hline Chelicerae $^{\mathrm{c}}$ & 12 & 360 & 21 & $330-390$ & 6.0 \\
\hline Procursus length (fig. 64) & 15 & 930 & 28 & $870-990$ & 3.1 \\
\hline Palpal femur length (fig. 63) & 15 & 1400 & 31 & $1340-1480$ & 2.3 \\
\hline Carapace width & 15 & 1630 & 73 & $1500-1810$ & 4.6 \\
\hline Tibia I length (dorsally) & 14 & 8460 & 374 & $7930-9070$ & 4.5 \\
\hline \multicolumn{6}{|l|}{ Female } \\
\hline Epigynum pockets, inner margins (fig. 66) & 27 & 300 & 49 & $230-400$ & 16.8 \\
\hline Epigynum pockets, outer margins (fig. 66 ) & 27 & 400 & 50 & $320-480$ & 13.1 \\
\hline Epigynum length (fig. 68) & 27 & 1110 & 567 & $530-1960$ & 53.1 \\
\hline Carapace width & 27 & 1390 & 152 & $1130-1680$ & 11.3 \\
\hline Tibia 1 length (dorsally) & 26 & 6510 & 829 & $5200-8000$ & 13.2 \\
\hline
\end{tabular}

aMeans and ranges are rounded to the nearest 10.

bCVs are corrected for bias, i.e., $[1+(1+1 / 4 \mathrm{~N}) \mathrm{CV}]$.

cDistance between tips of fang apophyses.

Caverna de Santo Tomás, Cueva de Catacumbas, Mar. 20, 1993 (L. Roque), 10 , in IES; Sierra de Quemados, Gran Caverna de Santo Tomás, Cueva de Antorcha, Mar. 19, 1993 (R. Travieso), 1 o , in IES; Sierra de San Carlos, Sistema Cavernario Majaguas-Cantera, Cueva de las dos Anas, Oct. 13, 1990 (A. Pérez González), 1 đิ 2 ㅇ (macrogynes) 1 juvenile, in IES; "Gramales, Cueva de los Murcielagos", Oct. 1991 (A. Pérez González), 10 , in IES; Viñales, Sistema Cavernario Palmarito, Apr. 16, 1998 (collector unknown), 2 우 (one macrogyne; epigynum missing in other female), in IES; "Cueva ?Mogalogeus (Catacumba)", Mar. 30, 1993 (E. Chong), floor, $1 \delta^{\star} 1$ 우 (macrogyne) 1 juvenile, in IES; Sierra del Infierno, Cueva del Campamento, Aug. 1992 (A. Pérez González), 29 (microgynes), in IES; Sierra de la Guira, Los Pinos Parque, Jan. 1995 (L. F. Armas), 1 우 (macrogyne), in IES.

\section{DISCUSSION}

Three of the four species described above show an unusual variation in the female gen-
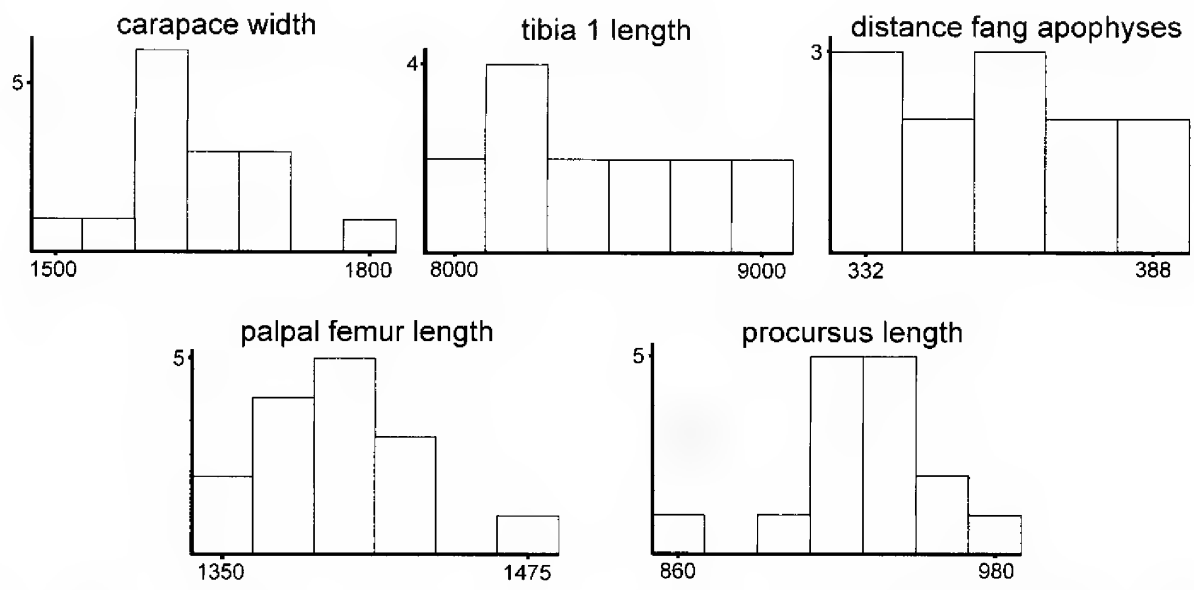

Fig. 73. Frequency distributions of some characters measured in 15 male $C$. antraia collected at the same locality on the same day. Measurements in micrometers. 

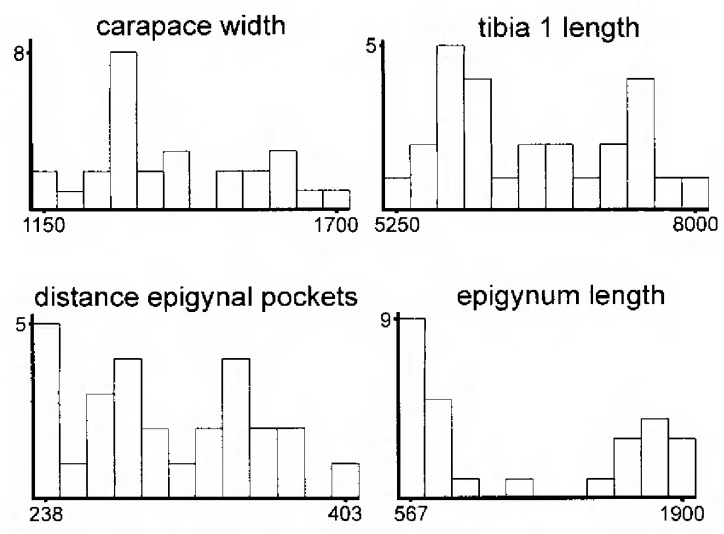

Fig. 74. Frequency distributions of some characters measured in 27 female $C$. antraia collected at the same locality on the same day. Note the distinct bimodality in epigynum length, with single intermediate morph. Measurements in micrometers.

italia. In two of them, sample size is very small, and the variation might be explained as a result of our having possibly erroneously lumped together varying specimens into one species. In $C$. antraia, however, the evidence strongly suggests that female genitalic dimorphism is actually occurring: (1) both types of females (which are easily distinguished in the field) were seen in close proximity at the type locality, often with a female of one type between two females of the other type; (2) all males collected from among the females had fairly identical genitalia, varying continuously in size; (3) the female epigynum comes in two types with a distinct "switch point" and rare intermediate forms; and (4) in the laboratory, microgyne and macrogyne mothers produced daughters of both morphs, proving conspecificity.

How common among spiders might such a phenomenon be? The literature suggests it is extremely rare, not only in spiders but in animals in general. The only two cases in the literature known to us are the seasonal dimorphisms in cicadas of the genus Euscelis, where the male copulatory organs differ between spring and summer generations (e.g., Kunze, 1959), and the dimorphism in the male

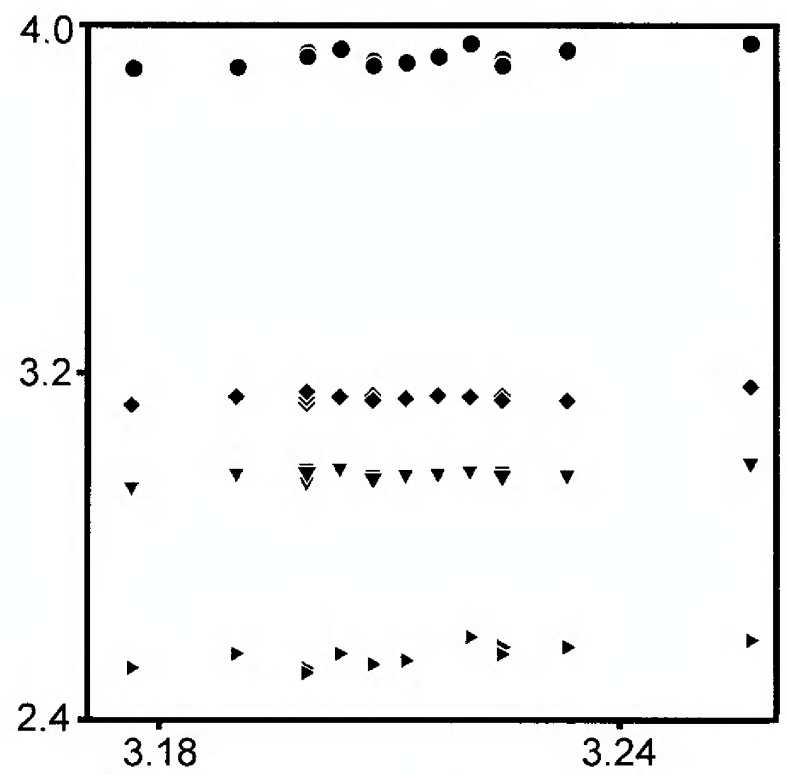

female

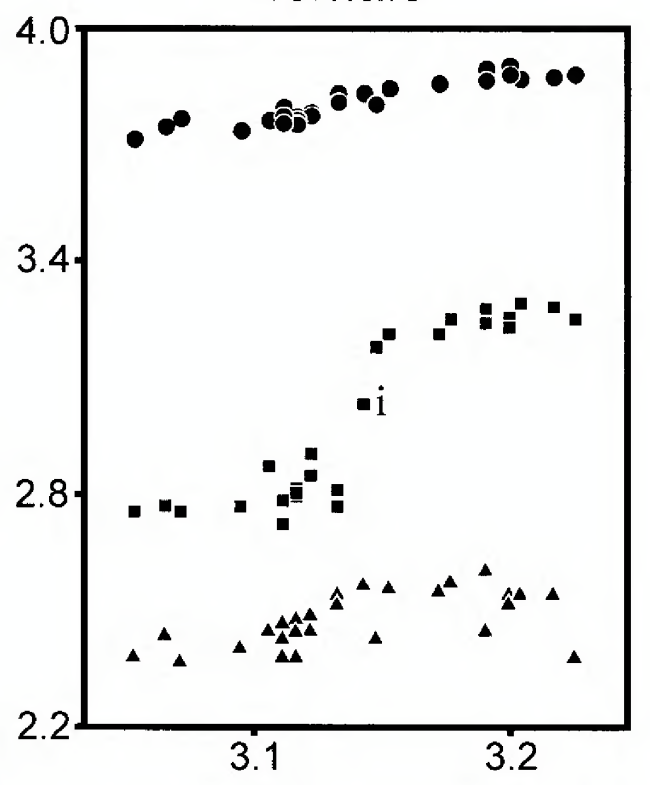

Fig. 75. Regressions of tibia 1 length $(\bullet)$, palpal femur length $(\bullet)$, procursus length $(\mathbf{\nabla})$, fang apophyses distance $(\boldsymbol{\nabla})$, epigynum length $(\boldsymbol{\square})$, and epigynal pockets distance $(\boldsymbol{\Delta})$ on carapace width (measurements in micrometers, $\log _{10}$ transformed). The strong compression of the Y-axes makes all male and the bottom and top female slopes almost horizontal and quite meaningless per se, but it emphasizes the difference to the sigmoidal relation between epigynum length and carapace width. " $i$ " = intermediate morph. 


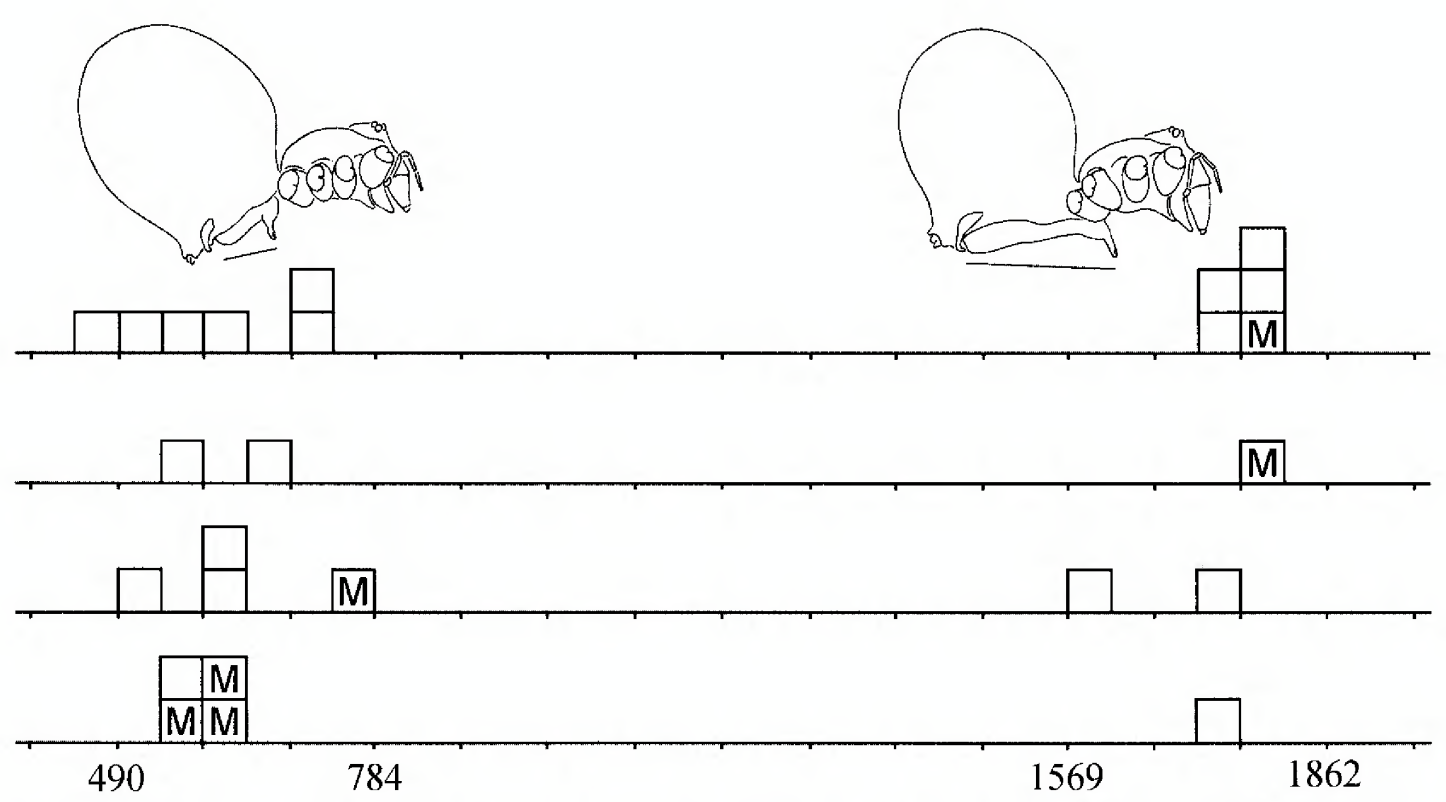

Fig. 76. Epigynum length in micrometers (cf. fig. 68) in six mothers ("M") and their daughters ( $\square$ ). In the lowest line the data from three mothers are pooled because their offspring were reared together in a single container. Note the absence of intermediate type females.

thrips Iotatubothrips kranzae Mound, Crespi, and Tucker, where macropterous males have significantly longer genitalia than micropterous males (Mound et al., 1998). However, we suggest the possibility that taxonomists are strongly biased against discovering genitalic dimorphisms (or polymorphisms), simply because genitalia are used with an overwhelming priority for species discrimination and identification. The necessary evidence for genitalic dimorphism is not easy to get. Combining this difficulty with the lack of any incentive to find it, or with the belief of its nonexistence, might easily explain the rarity of the phenomenon in the literature even if it were relatively common (i.e., as common as nongenitalic intrasexual polymorphisms).

What is the necessary evidence? Good evidence would be the copulation of males with both types of females (or females with both types of males in the case of male genitalic dimorphism), with the subsequent production of offspring. Such studies are still rare in spiders, and they might also be biased by selection of specimens that according to taxonomists belong to the same species (i.e., are of a single morph). Good evidence would also be the rearing of both types from a single female of either type. This is equally not easy, as the mortality of spiderlings is usually high due to specific diet requirements, cannibalism, and other factors. While a good number of spider species have been reared, this effort was apparently never directed at species with possible cases of genitalic dimorphism. A purely statistical approach on dead specimens might produce convincing evidence too, but this would depend on both large sample size and some minimal amount of information about the actual coexistence of both morphs in the same habitat. Sample size is often small, especially for tropical species where a considerable percentage of nominal species is known from a single specimen or a few specimens, often from various localities. Finally, most collections are assembled by generalists who have little or no time for observation of the necessary details.

In sum, while we have no evidence that female (or male) genitalic polymorphism is anything more than a rare curiosity, there is equally no evidence that it is not common.

\section{ACKNOWLEDGMENTS}

We thank various colleagues who responded to our initial inquiries about literature on 
polymorphisms: J. Coddington, W. G. Eberhard, C. Griswold, R. Jocque, and H. W. Levi. The American Museum of Natural History financed the 1999 collection trip and provided the first author with a Kalbfleisch Research Fellowship.

\section{REFERENCES}

Bryant, E. B.

1940. Cuban spiders in the Museum of Comparative Zoology. Bull. Mus. Comp.

Franganillo, P. B. Zool. 86(7): 247-532, pls. 1-22.

1930. Aracnidos de Cuba. Mas aracnidos nuevos de la Isla de Cuba. Mem. Inst. Nac. Mus. Hist. Nat. 1: 47-97.

1931. Excursiones aracnológicas, durante el mes de agosto de 1930. Rev. "Belen" 27-28, Año 6: 285-288.

Gertsch, W. J.

1982. The spider genera Pholcophora and Anopsicus (Araneae, Pholcidae) in North America, Central America and the West Indies. Bull. Assoc. Mex.
Cave Stud. 8: 95-144. Bull. Texas Mem. Mus. 28: 95-144.

Huber, B. A.

2000. New World pholcid spiders (Araneae: Pholcidae): a revision at generic level. Bull. Am. Mus. Nat. Hist. 254: 348 pp.

2001. The pholcids of Australia (Araneae: Pholcidae): taxonomy, biogeography, and relationships. Bull. Am. Mus. Nat. Hist. 260:140 pp.

Kunze, L.

1959. Die funktionsanatomischen Grundlagen der Kopulation der Zwergzikaden, untersucht an Euscelis plebejus (Fall.) und einigen Typhlocybinen. Dtsch. Entomol. Z. (NF) 6(4): 322-387.

Mound, L. A., B. J. Crespi, and A. Tucker

1998. Polymorphism and kleptoparasitism in thrips (Thysanoptera: Phalaeothripidae) from woody galls on Casuarina trees. Aust. J. Entomol. 37: 8-16.

Pérez González, A., and B. A. Huber

1999. Metagonia debrasi $\mathrm{n}$. sp. the first species of the genus Metagonia Simon in Cuba (Pholcidae, Araneae). Rev. Arachnol. 13(4): 69-72.

\section{APPENDIX 1}

Codings of Ciboneya nuriae for Cladistic Analysis (characters and codes are described in Huber, 2001)

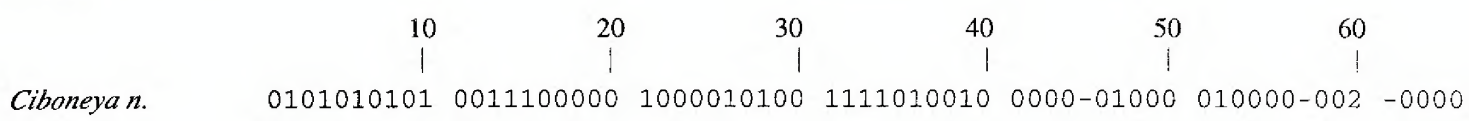


Recent issues of the Novitates may be purchased from the Museum. Lists of back issues of the Novitates and Bulletin published during the last five years are available at World Wide Web site http://nimidi.amnh.org. Or address mail orders to: American Museum of Natural History Library, Central Park West at 79th St., New York, NY 10024. TEL: (212) 769-5545. FAX: (212) 7695009. E-MAIL: scipubs@amnh.org

(2) This paper meets the requirements of ANSI/NISO Z39.48-1992 (Permanence of Paper). 